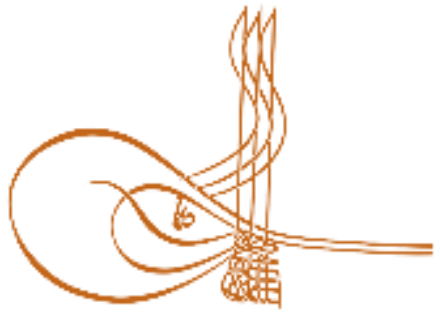

www.turkishstudies.net/social
Turkish Studies - Social Sciences

eISSN: $2667-5617$

Research Article / Araştırma Makalesi

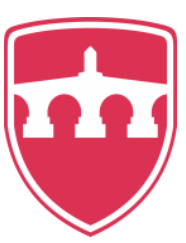

INTERNATIONAL

BALKAN

UNIVERSITY

Sponsored by IBU

\title{
Beden Eğitimi ve Spor Dersi Öğretim Programı Kazanımlarının Türkiye’deki Görme Engelliler Ortaokullarında Gerçekleşebilme Düzeyleri
}

\author{
The Possibility of Learning Outcomes of Gym and Sports Curriculum in Secondary Schools for the \\ Visually Impaired in Turkey
}

\author{
Sevda Kılıç* - Banu Altunay Arslantekin ${ }^{* *}$
}

\begin{abstract}
This study examined the views of teachers regarding the possibility of learning outcomes of gym and sports curriculum in secondary schools for the visually impaired in Turkey. The descriptive research (survey) model was utilized in order to describe and present current and actual experiences. While the population consisted of gym and sports teachers working at 16 M.N.E secondary schools for the visually impaired in 14 cities throughout Turkey, it was aimed to reach the entire limited population. Descriptive statistics were utilized in order to analyze the data, which were collected in one setting through a survey developed by the researcher, and the frequency distribution, central tendency and variability measures of each outcome were calculated. Lastly, the descriptive statistical distributions, in which the minimum, maximum, arithmetic mean, and standard deviation were calculated on the classroom basis, were included in order to assess the general situation. In the light of the findings obtained from the study, it was observed that the possible level of targeted behaviors in "Mobility Skills" and "Active and Healthy Life" learning domains were as "Medium-Level Competence". In addition, at the end of the survey, the participant teachers were asked to submit their opinions and suggestions and their suggestions might help to the study. These findings were interpreted that the insufficient qualification of the overall curriculum in terms of the developmental and educational needs of visually impaired students; the negative attitudes of school management, teachers, and parents towards gym and sports and mobility lessons; insufficient course hours; and the lack of tools and physical infrastructure might negatively affect the possibility of learning outcomes. It is thought that if the experts preparing the curriculum of the applied courses such as gym and sports which are in touch with life considered the theoretical targets as well as the practical targets of teachers and students, it would make it easier for the students with special needs to attain the targeted learning outcomes.
\end{abstract}

Structured Abstract: The urge for determining to what extent the learning outcomes within the scope of the

\footnotetext{
* Arş. Gör., Kafkas Üniversitesi, Dede Korkut Eğitim Fakültesi, Özel Eğitim Bölümü Res. Asst., Kafkas University, Faculty of Education, Department of Special Education ORCID 0000-0003-1522-654X sevdakilic@yahoo.com

** Doç. Dr. Gazi Üniversitesi Gazi Eğitim Fakültesi Özel Eğitim Bölümü Assoc. Prof. Dr. Gazi University, Gazi Faculty of Education, Department of Special Education ORCID 0000-0002-1202-1031

abanu@gazi.edu.tr

Cite as/ Atıf: Kılıç, S., Arslantekin, B. (2020). Beden Eğitimi ve Spor dersi öğretim programı kazanımlarının Türkiye'deki görme engelliler ortaokullarında gerçekleşebilme düzeyleri, Turkish Studies - Social, 15(3), 1275-1300. https://dx.doi.org/10.29228/TurkishStudies.41919

Received/Geliş: 25 February/Şubat 2020

Accepted/Kabul: 25 April/Nisan 2020

Copyright $(\mathrm{C}$ MDE, Turkey

Checked by plagiarism software

Published/Yayın: 30 April/Nisan 2020

CC BY-NC 4.0
} 
physical education, sports, and mobility lessons in secondary schools for the visually impaired fulfil the personal and educational needs of a student (e.g. To what extent the 7th grade learning outcome as "He/she displays his/her mobility skills with an increasing accuracy in games and activities that prepare for sports performed with rackets and long-handled tools" is gained to a visually impaired student) provided the basis for the conduction of the study. Hence, within this scope, considering each individual's right to education as well as the importance of mobility education on the child's development, the extent of the learning outcomes has to be determined in order to help the visually impaired students with different developmental characteristics and skills achieve the targets in sports and physical activities and mobility lessons. This study, accordingly, aims to identify the possibility level of learning outcomes of the applied curriculum within the scope of such lessons in secondary schools of the visually impaired in Turkey, and in accordance with this, to find out the extent of each outcome for the visually impaired students and which outcomes they have difficulty in getting.

In the light of this necessity and purpose, we sought an answer to the following main question.

What are the teachers' views on the possibility level of learning outcomes of sports and physical education curriculum in secondary schools of the visually impaired in Turkey?

In this study, the descriptive research (survey) model was utilized to help describe and explain what already exist and are experienced. The survey model (Creswell, 2017), which provides the quantitative or numerical description of trends, attitudes, or views across the population through the studies conducted on a sample selected from a population, can be classified from various perspectives. In parallel with the purpose of this study, the general survey model was deemed suitable in order to have a general opinion about the entire population in a population consisting of many elements (Karasar, 2014).

The entire limited population was tried to be reached while the physical education and sports teachers working at 16 M.N.E secondary schools for the visually impaired in 14 provinces throughout Turkey constituted the population of the study.

In accordance with the purpose of the study, the purposeful sampling method, which provides an opportunity for in-depth research by selecting information-rich cases, was preferred. In this sampling approach, which is preferred when it is needed to work on one or more specific cases that are unlikely, meet certain criteria, or have certain features, the researcher tries to understand the natural phenomena and public events or facts and to explore and explain the relationship between them (Büyüköztürk, Kılıç Çakmak, Akgün, Karadeniz, \& Demirel, 2016). Hence, the criteria of having at least 1-year professional service time and not being affected from total visual impairment were sought in physical education and sports teachers who participated in the study.

The data to be obtained within the scope of the study was planned to be gathered at once through the survey prepared by the researcher. Within the scope and at the stage of face validity of the questionnaire, first, the views and suggestions of 4 relevant field experts, 3 of whom were from the Faculty of Education and 1 from the School of Physical Education and Sports, were taken into consideration. Following the draft edits that proposed changes under the guidance of the field experts, the survey, which is an information gathering tool, was finalized. The survey consists of 3 parts as the articles determining the personal information (Part I), the articles determining the status of achievements (Part II), and the articles regarding the teachers' views on the learning outcomes of the applied curriculum (Part III).

In the analysis of the data, descriptive statistics were generally utilized, and frequency distributions, central tendency, and variability measures of each article/outcome were calculated. Lastly, in order to perform a general situation assessment, the descriptive statistics distributions where the minimum, maximum, arithmetic mean, and standard deviation were calculated at each grade level, were included.

In the light of the findings obtained from this study, where the teachers' views on the possibility level of learning outcomes of sports and physical education curriculum in secondary schools of the visually impaired in Turkey were reviewed, it was concluded that the possibility level of the targeted behaviors in "Mobility Skills" and "Active and Healthy Life" learning domains was as "Medium-Level Competence".

In addition, at the end of the survey, the teachers who participated in the study were asked to submit their views and suggestions that they thought could contribute to the research subject. The findings generally obtained from this part of the study were interpreted as the curricula which do not fulfil the developmental and educational needs of visually impaired students; the negative attitudes of school management, teachers, and

Turkish Studies - Social, 15(3) 
parents towards physical education, sports, and mobility lessons; and the insufficient course hours as well as the lack of equipment and physical infrastructure might have a negative impact on the possibility of learning outcomes. In this context, the urge for structuring the mobility education of the teachers participating in the study based on the groups affected by impairment as well as the urge for preparing a new functional curriculum in accordance with the developmental and educational needs of children with different potential, physical and/or mental characteristics and skills are parallel with the other research findings in the relevant literature. As it can be understood from this research result, which is in line with many studies in the related literature, there is a common consensus on the importance and necessity of a new and functional curriculum, which is suitable for the readiness levels of children with different developmental characteristics and skills and in which they can be aware of their interests, desires and abilities as an individual (Ayça, 2013; Çevrim, 2009; Demirci \& Toptaş Demirci, 2014; Duman, 2003; Ercan, 1991; Ertunç, 2008; Kayapınar \& Özüdoğru, 2010; Kaytaz, 2004; Kurtlar, 2009; Oral, Akyüz, Sindel, \& Aydın, 2012; Smagulova, 2009; Terzioğlu, 2002; Top, 2007; Toptaş Demirci et al., 2014; Türk, 2007; Usta, 2010).

As already known, the motor development of visually impaired students may differ from those who have normal motor development. It is thought that the fact that the learning outcomes of physical education and sports curriculum are prepared according to the students with usual developmental characteristics and do not fulfil the personal and educational needs of the students with different developmental characteristics make it difficult for the students with different developmental characteristics to achieve the learning outcomes in the curricula, and thus prevent the equal opportunities in education. It is thought that the fact that the developmental characteristics and needs of the visually impaired students are not taken into consideration when determining the learning outcomes prevent these students from achieving the targets in physical education, sports and mobility lessons effectively and efficiently. It is thought that if the field experts who prepare the curriculum of applied courses in touch with life, such as physical education and sports lessons, considered the theoretical targets as well as the practical targets of teachers and students, it would make it easier for students with disabilities to achieve the intended targets.

Keywords: Visually Impaired Children, Gym and Sports Curriculum, Learning Outcomes, Views of Teachers

Öz: Beden eğitimi ve spor dersi öğretim programı kazanımlarının Türkiye’deki görme engelliler ortaokullarında gerçekleşebilme düzeylerine ilişkin öğretmen görüşlerinin değerlendirildiği bu araştırmada hali hazırda var olanların, yaşananların ne olduğunun betimlenip açıklanarak ortaya konulmasını sağlayan betimsel araştırma (tarama, survey) modelinden yararlanılmıştır. Türkiye genelinde 14 ilde yer alan Milli Eğitim Bakanlığına bağlı 16 görme engelliler ortaokulunda görev yapan beden eğitimi ve spor öğretmenleri araştırmanın evrenini oluştururken, sınırlı sayıdaki evrenin tamamına ulaşılmaya çalışılmıştır. Araştırmacı tarafından oluşturulan anket aracılığıyla tek seferde toplanan verilerinin analizinde betimsel istatistikten yararlanılmış olup her bir maddeye/kazanıma ait frekans dağılımları, merkezi eğilim ve değişkenlik ölçüleri hesaplanmıştır. Son olarak genel bir durum değerlendirmesinin yapılabilmesi amacıyla her bir sınıf düzeyinde minimum, maksimum, aritmetik ortalama ve standart sapmanın hesaplandığ $\breve{l}_{1}$ betimsel istatistik dağ 1 lımlarına yer verilmiştir. Araştırmadan elde edilen bulgular 1şığında, "Hareket Yetkinliği”" ve "Aktif ve Sağlıklı Yaşam" öğrenme alanlarına ilişkin kazandırılması hedeflenen davranışların gerçekleşebilme düzeylerinin "Orta Düzey Yeterlik" şeklinde olduğunu sonucuna ulaşılmıştır. Ayrıca yapılan anket çalışmasının sonunda, araştırmaya katılan öğretmenlerden araştırma konusuna yardımcı olabileceklerini düşündükleri görüş ve önerilere yer verilmesi istenmiş olup araştırmanın bu bölümünden elde edilen bulgular genel anlamda öğretim programlarının görme yetersizliğinden etkilenen öğrencilerin gelişimsel ve eğitimsel ihtiyaçlarını karşılayıcı nitelikte olmayışının; okul yönetimi, öğretmen ve velilerin beden eğitimi, spor ve bağımsız hareket dersine ilişkin olumsuz tutumlarının; yetersiz ders saatlerinin, araç-gereç ve fiziki alt yapı eksikliklerinin kazanımların gerçekleşebilme durumlarına olumsuz etki edebileceği şeklinde yorumlanmıştır. Beden eğitimi ve spor dersi gibi yaşamla iç içe olan uygulamalı derslerin öğretim programlarını hazırlayan alan uzmanlarının teorideki hedeflerin yanı sıra öğretmen ve öğrencilerin uygulamadaki hedeflerini de dikkate almaları özel gereksinimleri olan öğrencilerin kazandırılması amaçlanan hedeflere ulaşmalarını kolaylaştıracağı düşünülmektedir.

Anahtar Kelimeler: Görme Yetersizliğinden Etkilenen Çocuklar, Beden Eğitimi ve Spor Dersi Öğretim Programı, Kazanımlar, Öğretmen Görüşleri. 


\section{Giriş}

Türkiye'de Milli Eğitim politika ve uygulamalarını belirleyen bazı uluslararası ve ulusal düzeyde yasal düzenlemeler vardır. İnsan Hakları Evrensel Beyannamesi (IHEB) ile Çocuk Haklarına Dair Sözleşme (ÇHS) ülkemizin de imzaladığı uluslararası belgeler arasındadır (Dağlı, 2007). İHEB, Birleşmiş Milletler Örgütüne üye devletlerce ayrım gözetmeksizin bütün insanlara tanınan temel hak ve hürriyetlere eğitim-öğretim yolu ile saygı geliştirmeyi amaçlamaktadır (Resmi Gazete, 1949; UNICEF, 2016b). Çağdaş eğitim, geleneksel eğitimde olduğu gibi çocuğa "gelişmemiş bir yetişkin" olarak değil kendine özgü gereksinimleri ve hakları bulunan, korunması gereken bir varlık olarak bakmakta ve bu anlayışın sonucu olarak da 20 Kasım 1989 tarihinde içinde Türkiye'nin de bulunduğu 191 ülke tarafindan kabul edilen ve tarihte en çok kabul gören insan hakları belgesi niteliğini taşıyan ÇHS imzalanmaktadır. Her şeyden önce çocuğun yüksek yararının göz önünde tutulduğu, üzerinde pazarlık yapılması mümkün olmayan standartlar ve yükümlülükler yer alan ÇHS'de taraf devletler çocuğun toplumsal, ruhsal ve ahlaki esenliği ile bedensel ve zihinsel sağlığını geliştirmeye yönelik yasal, toplumsal, eğitsel ve yönetimsel bütün önlemleri alarak çocuğun hayatta kalması ve gelişmesi için mümkün olan azami çaba dahilinde hareket ederler. ÇHS'nin 31. maddesine göre,

"Taraf Devletler çocuğun dinlenme, boş zaman değerlendirme, oynama ve yaşına uygun eğlence (etkinliklerinde) bulunma, kültürel ve sanatsal yaşama serbestçe katılma hakkını tanırlar. Taraf Devletler, çocuğun kültürel ve sanatsal yaşama tam olarak katılma hakkını saygı duyarak tanırlar ve özendirirler ve çocuklar için, boş zamanı değerlendirmeye, dinlenmeye, sanata ve kültüre ilişkin (etkinlikler) konusunda uygun ve eşit fırsatların sağlanmasını teşvik ederler." (Resmi Gazete, 1995).

$\mathrm{Bu}$ maddeden de anlaşılacağ gibi taraf devletlerin eğitim politika ve uygulamalarından beklenen, çocukların gizil güç ve yeteneklerinin ortaya çıarılarak en üst düzeyde geliştirilmesine yardımcı olmakla birlikte çocuğun bedensel, zihinsel, duygusal, ahlaksal ve sosyal yönleriyle bir bütün olarak yetiştirilmesidir. Nitekim bu bağlamda, bir ulusun geleceği, yetişmiş ve yetişmekte olan çocukların gelişim bütünlüğüne bağlanırken; uygarlık bireye verilen önem ve bu önemle bağlantılı olarak ona verilen eğitime dayandırılmaktadır (Arac1, 2006; Dağlı, 2007; UNICEF, 2016a).

Türkiye'de milli eğitim politikalarını ve uygulamalarını belirleyen ulusal düzeyde yasal düzenlemelerin başında ise Türkiye Cumhuriyeti Anayasası'nın 5. maddesi yer almaktadır. Bu maddeye göre,

“Devletin temel amaç ve görevleri; Türk Milleti’nin bağımsızlığını ve bütünlüğünü, ülkenin bölünmezliğini, Cumhuriyeti ve demokrasiyi korumak; kişilerin ve toplumun refah, huzur ve mutluluğunu sağlamak; kişilerin temel hak ve hürriyetlerini, sosyal hukuk devleti ve adalet ilkeleriyle bağdaşmayacak suretle sınırlayan siyasal, ekonomik ve sosyal engelleri kaldırmaya, insanın maddi ve manevi varlığının gelişmesi için gerekli şartları hazırlamaya çalışmaktır.” (Resmi Gazete, 1982).

Eğitimin bir diğer hukuksal temelini de Türkiye Cumhuriyeti Anayasası'nın 42. maddesi oluşturmaktadır. Bu maddeye göre, "Eğitim ve öğrenim hakkı ve ödevi; Kimse, eğitim ve öğretim hakkından yoksun bırakılamaz." (Resmi Gazete, 1982). Böylece her vatandaşın eğitim ve öğrenim hakkının olduğu kesin olarak anayasada yer almaktadır. Ayrıca 1973 yılında çıkan 1739 sayılı Milli Eğitim Temel Kanunu (METK) da bu hakkı desteklemektedir. METK'nın 7. maddesine göre, "Temel Eğitim görmek her Türk vatandaşının hakkıdır." (Resmi Gazete, 1973). Ulusal düzeydeki bu yasal düzenlemeler çerçevesinde, eğitim hakkının tüm bireyler tarafından kullanılması eğitimde firsat eşitliğinin sağlanmasını zorunlu kılmaktadır. Tüm bu uluslararası ve ulusal düzeydeki yasal düzenlemelerden de anlaşılacağı üzere, çocukların gelişim özellikleri göz önünde tutularak kişisel ve toplumsal yönden sağlıklı, mutlu, ahlaklı, yaratıcı ve üretken bireyler olarak yetiştirilmelerinde hareket eğitiminin önemi ortaya çıkmaktadır (Sarpkaya, 2008). 
İnsan organizmasının hareket halinde olması, organizmanın normal fonksiyonlarını devam ettirmesinde ve sağlıklı olmasında büyük bir öneme sahiptir. Çocuğun yaşamında hareket, doğal bir eylem olup hareket eğitimiyle çocukların vücutlarını tanıyıp doğru kullanmalarına, fiziksel uygunlukları hakkında bilgi sahibi olmalarına ve hareket potansiyellerini uygun spor etkinliklerinde değerlendirmelerine yardımcı olunur. Hareket eğitimiyle çocuklara duygularını ifade etme, kişisel amaçlar belirleme, özgürce hareket etme ve paylaşmayı öğrenme gibi birçok olumlu davranış örüntüleri kazandırılabilir. Eğitimin insanın beden sağlığını ve becerilerini geliştirmeye yönelik dalı olan beden eğitimini; hareket etmeyi öğrenme ve hareket yoluyla öğrenmeyi amaçlayan, genel eğitimin amaçlarına hareket aracılığıyla katkıda bulunan, bireyin öğrenme ve gelişim alanlarına katkı sağlamak amacıyla organize edilmiş bedensel etkinliklerin tümü olarak tanımlayabiliriz (Aracı, 2006; Muratlı, 2007; Tüfekçioğlu, 2003). Koparan (2003), terapötik özelliği bulunan hareket eğitim programlarının farklı gelişimsel özellik ve yeteneklere sahip bireylerin ihtiyaçları doğrultusunda özel olarak hazırlanmasının önemine değinirken, bu bireylerin aktivite planlarının ilk aşamasında adapte edici (uyarlanmış) fiziksel eğitim programlarına, ikinci aşamasında iyileştirici fiziksel eğitim programlarına ve son aşamasında ise geliştirici fiziksel eğitim programlarına yer verilmesi gerekliliğinin altını çizmiştir. Yine bu doğrultuda, Konar ve Pepe (2003), özel gereksinimleri olan bireylerin toplumsal entegrasyonları ve rehabilitasyonlarında gelişim özelliklerine uygun spor aktivitelerin önemi ve gerekliliğinden hareketle, farklı gelişimsel özellik ve yeteneklere sahip bireylerin motorik, ruhsal ve sosyal alanlardaki gelişimlerini destekleyici nitelikteki rehabilitasyon sporunun yaygınlaştırılıp teşvik edilmesi ve özel eğitim kurumlarında görev yapacak beden eğitimi ve spor öğretmenlerinin yetersizlikten etkilenme gruplarına göre özel olarak yetiştirilmesi hususunda vurguda bulunmuşlardır. Türk (2007), çalışmasında görme yetersizliğinden etkilenen öğrencilerin hareket özgürlüğü sorunlarının çözümü için en uygun ders olarak görülen beden eğitimi dersinin gerek içerik gerekse eğitim personelinin farklı gelişimsel özellik ve yeteneklere sahip bu öğrencileri eğitmeye yeterli hale getirilmesi gerekliliğinin altını çizerken, bu gerekliliğin ise ancak alanında uzman eğitimciler eşliğinde mümkün olabileceğini ifade etmiştir. Ayrıca iyi düzenlenmiş bir hareket eğitim programının gelişimsel farklılıkları bulunan bireyler için rehberlik ve rehabilitasyon hizmetlerini içerdiği pek çok araştırmacı tarafından vurgulanmaktadır (Ayça, 2013; Çalışkan, Pehlivan, İnal, Dane ve Akar, 2006; Çebi, 2013; Doğan, 2010; Kılıçoğlu, 2006; Kızar, 2012; Konar ve Pepe 2003; Konar ve Yıldıran, 2012; Koparan, 2003; Çelik Kayapınar ve Özüdoğru, 2010; Kurtlar, 2009; Özer, 2005; Terzioğlu, 2002; Top, 2007; Tuç, 2010; Türk, 2007; Uslu ve Shakouri, 2012; Usta, 2010).

Görme engelliler ortaokullarında beden eğitimi, spor ve bağımsız hareket dersi kapsamında uygulanmakta olan öğretim programı kazanımlarının, örneğin; "Raket ve uzun saplı araçlarla yapılan sporlara hazırlayıcı oyun ve etkinliklerde hareket becerilerini artan bir doğrulukta sergiler." 7. sınıf kazanımının görme yetersizliğinden etkilenen bir öğrenciye ne derecede kazandırıldığının, öğrencinin bireysel ve eğitimsel ihtiyaçlarına ne düzeyde cevap verdiğinin belirlenmesi isteği araştırmanın oluşturulmasına zemin hazırlamıştır. Nitekim bu bağlamda hareket eğitiminin her bireyin eğitim-öğretim hakkından ve çocuk gelişimi üzerindeki öneminden hareketle görme yetersizliğinden etkilenen, farklı gelişimsel özellik ve yeteneklere sahip öğrencilerin beden eğitimi, spor ve bağımsız hareket dersinde hedeflenen amaçlara ulaşmalarına katkıda bulunmak amacıyla kazanımlara ne düzeyde ulaşıldığının belirlenmesini gerekli kılmaktadır. Araştırma bu gereklilik doğrultusunda Türkiye' deki görme engelliler ortaokullarında bu ders kapsamında uygulanmakta olan öğretim programı kazanımlarının gerçekleşebilme durumlarına ilişkin bir durum saptaması yapma ve bu durum saptaması doğrultusunda görme yetersizliğinden etkilenen öğrencilerin hangi kazanımları ne düzeyde elde edebildiklerini ve hangi kazanımları elde etmede güçlük yaşadıklarını ortaya çıkarma amacındadır.

Araştırmada bu gereklilik ve amaç 1şığında aşağıdaki sorulara yanıt aranmıştır.

Beden eğitimi ve spor dersi öğretim programı kazanımlarının Türkiye'deki görme engelliler 
ortaokullarında gerçekleşebilme düzeyine ilişkin öğretmen görüşleri nelerdir?

Belirlenen bu problem cümlesi ışığında aşağıda belirtilen alt problemler oluşturulmuştur.

Türkiye'deki görme engelliler ortaokullarında görev yapan beden eğitimi ve spor öğretmenlerinin görüşlerine göre;

1. Beden eğitimi ve spor dersi öğretim programında yer alan 5. sınıf kazanımlarının gerçekleşebilme düzeyleri nedir?

2. Beden eğitimi ve spor dersi öğretim programında yer alan 6. sınıf kazanımlarının gerçekleşebilme düzeyleri nedir?

3. Beden eğitimi ve spor dersi öğretim programında yer alan 7. sınıf kazanımlarının gerçekleşebilme düzeyleri nedir?

4. Beden eğitimi ve spor dersi öğretim programında yer alan 8. sınıf kazanımlarının gerçekleşebilme düzeyleri nedir?

\section{Yöntem}

\section{Araştırmanın Modeli}

$\mathrm{Bu}$ araştırmada hali hazırda var olanların, yaşananların ne olduğunun betimlenip açıklanarak ortaya konulmasını sağlayan betimsel araştırma (tarama, survey) modelinden yararlanılmıştır. Betimsel araştırmalarda, üzerinde çalışılan doğal ve toplumsal olguların kontrol edilme durumu söz konusu değildir. Başka bir ifadeyle ortama yeni bir değişken sokulmazken, olgu neyse ve nasıl işliyorsa öyle ele alınır ve akışına müdahale edilmeksizin incelenir. Yani araştırmacı, araştırma etkinliğine katılsa da katılmasa da olgu aynı şeklide varlığını sürdürecektir. Genel anlamda olgunun ne olduğunun olabildiğince aynen ortaya konulması betimsel araştırmaların toplum bilimlerince en çok kullanılan araştırma yöntemi olmasına katkı sağlamıştır. Bunun yanı sıra görünüşün bir fotoğrafının çekilmeye çalışılmasından dolayı gerek başlangıcında gerekse de sonunda bulguların yorumlanmasında betimsel araştırmaların deneysel araştırmalara büyük bir katk1 sağlayabileceği düşünülmektedir. Ayrıca güncel sorunların çözümlenmesinde de etkili bir şekilde kullanılabileceği ileri sürülmektedir (Sönmez ve Alacapınar, 2014). Bir evren içinden seçilen bir örneklem üzerinde yapılan çalışmalar yoluyla evren genelindeki eğilim, tutum veya görüşlerin nicel veya nümerik olarak betimlenmesini sağlayan tarama modeli (Creswell, 2017), çeşitli açılardan sınıflandırılabilmektedir. $\mathrm{Bu}$ araştırmanın amacı doğrultusunda çok sayıda elemandan oluşan bir evrende evrenin tamamı hakkında genel bir yargıya varmak amacıyla genel tarama modelinin kullanılması uygun görülmüştür (Karasar, 2014).

\section{Araştırmanın Evreni}

Adana / Çukurova-Oğuz Kağan Köksal Görme Engelliler Ortaokulu,

Ankara / Yenimahalle - Mitat Enç Görme Engelliler Ortaokulu,

Ankara / Altındağ - Göreneller Görme Engelliler Ortaokulu,

Çanakkale / Gelibolu - Yahya Çavuş Görme Engelliler Ortaokulu,

Denizli / Merkezefendi - Eğitim Kurumları Yaptırma ve Yaşatma Derneği Denizli Görme Engelliler Ortaokulu,

Diyarbakir / Yenişehir - Ali İhsan Arslan Görme Engelliler Ortaokulu,

Erzurum / Yakutiye - Erzurum Görme Engelliler Ortaokulu,

Gaziantep / Şehitkamil - GAP Görme Engelliler Ortaokulu,

İstanbul / Üsküdar - Türkan Sabancı Görme Engelliler Ortaokulu, 
İstanbul / Sarıyer - Veysel Vardar Görme Engelliler Ortaokulu,

İzmir / Bornova - Aşık Veysel Görme Engelliler Ortaokulu,

Kahramanmaraş / Onikişubat - Ertuğrulgazi Görme Engelliler Ortaokulu,

Kayseri / Kocasinan - Emel Tarman Görme Engelliler İlkokulu,

Konya / Selçuklu - Selçuklu Mediha-Hasan Tahsin Alaylı Görme Engelliler Ortaokulu,

Niğde / Merkez - Cemil Meriç Görme Engelliler Ortaokulu,

Tokat / Merkez - Mehmet Akif Ersoy Görme Engelliler Ortaokulu olmak üzere Türkiye genelinde 14 ilde yer alan Milli Eğitim Bakanlığına bağl 16 görme engelliler ortaokulunda görev yapan beden eğitimi ve spor öğretmenleri araştırmanın evrenini oluştururken, sınırlı sayıdaki evrenin tamamına ulaşılmaya çalışılmıştır.

\section{Araştırmanın Örneklemi}

Beden eğitimi ve spor dersi öğretim programı kazanımlarının Türkiye'deki görme engelliler ortaokullarında gerçekleşebilme düzeylerine ilişkin öğretmen görüşlerinin değerlendirildiği bu araştırmada, araştırmanın amacına bağlı olarak bilgi açısından zengin durumların (information-rich cases) seçilerek derinlemesine araştırma firsatı sağlayan amaçsal (amaçlı) örnekleme yöntemi tercih edilmiştir. Olasılığı olmayan, belirli ölçütleri karşılayan veya belirli özelliklere sahip olan bir veya daha fazla özel durum üzerinde çalışılmak istendiğinde tercih edilen bu örnekleme yaklaşımında araştırmacı, seçilen durumlar bağlamında doğa ve toplum olaylarını ya da olgularını anlamaya ve bunlar arasındaki ilișkileri keșfetmeye ve açıklamaya çalıșmaktadır (Büyüköztürk, Kılıç Çakmak, Akgün, Karadeniz ve Demirel, 2016). Nitekim bu bağlamda araştırmaya katılan beden eğitimi ve spor öğretmenlerinde en az 1 yıl mesleki hizmet süresine sahip olma ve total görme yetersizliğinden etkilenme durumunun olmaması ölçütleri aranmıştır.

Araştırmaya katılan beden eğitimi ve spor öğretmenlerinin demografik özellikleri Tablo 1 'den yararlanılarak aşağıda verilmiştir.

Tablo 1: Araştırmaya Katılan Beden Eğitimi ve Spor Öğretmenlerinin Demografik Özellikleri

\begin{tabular}{|c|c|c|c|}
\hline Bağımsız Değişkenler & Alt Kategoriler & $\mathbf{n}$ & $\%$ \\
\hline \multirow[t]{2}{*}{ Cinsiyet } & Kadın & & \\
\hline & Erkek & 13 & 100,0 \\
\hline \multirow[t]{5}{*}{ Yaş } & $20-25$ & & \\
\hline & $26-30$ & & \\
\hline & $31-35$ & 1 & 7,7 \\
\hline & $36-40$ & 5 & 38,5 \\
\hline & 41 ve üzeri & 7 & 53,8 \\
\hline \multirow[t]{5}{*}{ Mesleki Hizmet Süresi } & $1-5 \mathrm{y} 1 \mathrm{l}$ & 1 & 7,7 \\
\hline & $6-10 \mathrm{y} 11$ & 2 & 15,4 \\
\hline & $11-15 \mathrm{y} 1 \mathrm{l}$ & 6 & 46,2 \\
\hline & $16-20 \mathrm{y} 1 \mathrm{l}$ & 4 & 30,8 \\
\hline & 21 yıl ve üzeri & & \\
\hline \multirow[t]{2}{*}{ Mezun Olunan Bölüm } & $\begin{array}{c}\text { Beden Eğitimi ve Spor } \\
\text { Öğretmenliği }\end{array}$ & 13 & 100,0 \\
\hline & Diğger & & \\
\hline \multirow[t]{2}{*}{ Görme Yetersizliği Durumu } & Var & & \\
\hline & Yok & 13 & 100,0 \\
\hline $\begin{array}{l}\text { Kısaltmalar: n: Kişi Sayısı, N: Toplam Kişi } \\
\text { Sayısı, \%: Yüzde }\end{array}$ & & 13 & 100,0 \\
\hline
\end{tabular}

Araştırmaya katılan beden eğitimi ve spor öğretmenlerinin demografik özellikleri Tablo 1'den yararlanılarak aşağıda verilmiştir. 
Tablo 1'de görüldüğü gibi, araştırmaya tamamı erkek olmak üzere toplam $13(\% 100,0)$ beden eğitimi ve spor öğretmeni dahil edilmiştir. \%53,8'lik bir oranla 7 öğretmen, 41 ve üzeri yaş grubu olarak yoğunluğun en fazla olduğu grubu oluştururken; \%46,2'lik bir oranla 6 öğretmen ise 11-15 yıl mesleki hizmet süresine sahip olarak yoğunluğun en fazla olduğu grubu oluşturmuştur. Ayrıca araştırmaya katılan beden eğitimi ve spor öğretmenlerinin tamamının beden eğitimi ve spor öğretmenliği bölümünden mezun oldukları ve herhangi bir görme yetersizliği durumundan etkilenmedikleri tespit edilmiştir.

\section{Veri Toplama Yöntemi}

Araştırma kapsamında elde edilecek verilerin, araştırmacı tarafından oluşturulan anket aracılığıyla tek seferde toplanması planlanmıştır. Hazırlanan anketin kapsam ve görünüş geçerliliği aşamasında öncelikle 3'ü Eğitim Fakültesi, 1'i Beden Eğitimi ve Spor Yüksekokulu'ndan olmak üzere 4 ilgili alan uzmanının görüş ve önerileri dikkate alınmıştır. Alan uzmanlarının rehberliğinde değişiklik öngören taslak düzenlemelerden sonra bilgi toplama aracı olan ankete son şekli verilmiştir. Hazırlanan anket; kişisel bilgileri belirleyici maddeler (I. Bölüm), kazanımlara yönelik durum belirleme maddeleri (II. Bölüm) ve uygulanmakta olan öğretim programı kazanımlarına yönelik öğretmen görüşleri maddeleri (III. Bölüm) olmak üzere 3 bölümden oluşmaktadır.

Alt araştırma problemlerinin çözümüne katkı sağlayacak olan 5., 6. ve 7. sınıf kazanımları, Beden Eğitimi ve Spor Dersi Öğretim Programı (MEB, 2013) doğrultusunda hazırlanmış olup 8. sınıf kazanımları ise araştırma esnasında kullanımına halen devam edilen eski İlköğretim Beden Eğitimi Dersi (1-8. Sınıflar) Öğretim Programı (2006) doğrultusunda hazırlanmıştır. Bu öğretim programlarınca ele alınan kazanımların gerçekleşebilme düzeylerine ilişkin olarak öğretmenlerden beşli likert tipi dereceleme (Tamamen, Büyük Ölçüde, Kısmen, Çok Az, Hiç) şeklinde hazırlanan maddelerden yalnızca sorumlu oldukları sinıf düzeyinin (5. sınıf 30 kazanım, 6. sinıf 30 kazanım, 7. sınıf 31 kazanım, 8. Sınıf 37 kazanım) değerlendirilmesi istenilmiştir. Ayrıca programlarda yer alan kazanımların gerçekleşebilme düzeylerinin belirlenebilmesi amacıyla anket çalışmasının 2016 yılı Mayıs ayı sonunda uygulanması uygun görülmüştür.

\section{Verilerin Analizi}

Verilerin analizinde araştırmacı tarafından toplanan anket formları öncelikle kontrol edilerek eksik ve/veya yanlış doldurulanlar araştırma dışında tutulmuştur. Toplanan anketlerden kabul edilebilir nitelikte olanlar ise SPSS 20 (Statistical Package for Social Scientists for Windows Release) paket programında değerlendirilmek üzere kodlanarak bilgisayar ortamına aktarılmıştır.

5'li likert tipi dereceleme şeklinde düzenlenen maddelerin puanlandırılmasında ankette yer alan tüm maddelerin olumlu cümle yapısında olması nedeniyle tersi bir puanlamaya gerek duyulmamış ve Tamamen (5), Büyük Ölçüde (4), Kısmen (3), Çok Az (2), Hiç (1) şeklinde puanlandırılmıştır. Aritmetik ortalama değerlendirme aralıklarının hesaplanmasında ise en yüksek puanlandırma değeri olan 5'ten, en küçük puanlandırma değeri olan 1 çıkarılmış ve elde edilen 4 sayısı, 5 olan seçenek sayısına bölünmüştür. Bu işlem sonucunda aralık katsayısı .80 bulunmuş ve aşağıda yer alan kazanımların gerçekleşebilme durum seçenekleri belirlenmiştir (Toptaş Demirci, Çınar ve Demirci, 2014). 
Tablo 2: Kazanımların Gerçekleşebilme Düzeylerine İlişkin Aritmetik Ortalama Değerlendirme Aralıklarınının Oluşturulması

\begin{tabular}{cccc}
\hline Aralık & $\begin{array}{c}\text { Kazanımların } \\
\text { Gerçekleşebilme } \\
\text { Durum Seçenekleri }\end{array}$ & Aralığın Değeri & Değerlendirme \\
\hline $1.00-1.80$ arası & Hiç & $\begin{array}{c}\text { "Çok Olumsuz" puan } \\
\text { aralığı }\end{array}$ & Yetersiz \\
\hline $1.81-2.60$ aras1 & Çok Az & "Olumsuz" puan aralığı & Alt Düzey Yeterlik \\
\hline $2.61-3.40$ arası & Kısmen & "Orta" puan aralığı & Orta Düzey Yeterlik \\
\hline $3.41-4.20$ aras1 & Büyük Ölçüde & "Olumlu" puan aralığı & Üst Düzey Yeterlik \\
\hline $4.21-5.00$ arası & Tamamen & $\begin{array}{c}\text { "Çok Olumlu" puan } \\
\text { aralığı }\end{array}$ & En Üst Düzey Yeterlik \\
\hline
\end{tabular}

Tablo 2'de oluşturulan bu renk skalas1; bulgular bölümündeki aritmetik ortalama aralıklarının değerlendirilmesi ve kazanımların gerçekleşebilme düzeylerine göre sınıflandırılması aşamalarında, görsel ayırt ediciliğin arttırılması amacıyla kullanılmıştır.

"Kazanımlara Yönelik Durum Belirleme Maddeleri" verilerinin analizinde genel anlamda betimsel istatistikten yararlanılmış olup her bir maddeye/kazanıma ait frekans dağılımları, merkezi eğilim ve değișkenlik ölçüleri hesaplanmıștır. Son olarak genel bir durum değerlendirmesinin yapılabilmesi amacıyla her bir sinıf düzeyinde minimum, maksimum, aritmetik ortalama ve standart sapmanın hesaplandığı betimsel istatistik dağılımlarına yer verilmiştir.

\section{Bulgular}

\section{Birinci Alt Probleme İlişkin Bulgular}

5. sınıf beden eğitimi ve spor dersi öğretim programı kazanımlarının gerçekleşebilme düzeylerine ilişkin betimsel istatistik dağılımları Tablo 3 ve Ek 1'den yararlanılarak aşağıda verilmiştir. 
Tablo 3: 5. Sınıf Kazanımlarının Gerçekleşebilme Düzeylerine İlişkin Betimsel İstatistik Dağılımlanı

$\begin{array}{llllllll}\text { Kazanımlar } & \text { Tamamen } & \begin{array}{c}\text { Büyük } \\ \text { Ölçüde }\end{array} & \text { Kısmen } & \text { Çok Az } & \text { Hiç } & \overline{\mathbf{X}} & \text { Ss }\end{array}$

\begin{tabular}{|c|c|c|c|c|c|c|c|c|c|c|c|c|}
\hline Madde No & $\mathrm{n}$ & $\%$ & $\mathrm{n}$ & $\%$ & $\mathrm{n}$ & $\%$ & $\mathrm{n}$ & $\%$ & $\mathrm{n}$ & $\%$ & & \\
\hline 1. & & & 9 & 69,2 & 4 & 30,8 & & & & & 3,69 & 0,48 \\
\hline 2. & & & 7 & 53,8 & 4 & 30,8 & 2 & 15,4 & & & 3,38 & 0,768 \\
\hline 3. & & & 9 & 69,2 & 3 & 23,1 & 1 & 7,7 & & & 3,62 & 0,65 \\
\hline 4. & & & 7 & 53,8 & 4 & 30,8 & 2 & 15,4 & & & 3,38 & 0,768 \\
\hline 5. & & & 1 & 7,7 & 6 & 46,2 & 6 & 46,2 & & & $2,62 * * *$ & 0,65 \\
\hline 6. & & & & & 8 & 61,5 & 5 & 38,5 & & & $2,62 * * *$ & 0,506 \\
\hline 7. & & & & & 1 & 7,7 & 9 & 69,2 & 3 & 23,1 & $1,85^{*}$ & 0,555 \\
\hline 8. & 1 & 7,7 & 9 & 69,2 & 2 & 15,4 & 1 & 7,7 & & & 3,77 & 0,725 \\
\hline 9. & 2 & 15,4 & 7 & 53,8 & 4 & 30,8 & & & & & 3,85 & 0,689 \\
\hline 10. & 1 & 7,7 & 7 & 53,8 & 3 & 23,1 & 2 & 15,4 & & & 3,54 & 0,877 \\
\hline 11. & 3 & 23,1 & 7 & 53,8 & 2 & 15,4 & 1 & 7,7 & & & $3,92 *$ & 0,862 \\
\hline 12. & 2 & 15,4 & 9 & 69,2 & 2 & 15,4 & & & & & $4,00 *$ & 0,577 \\
\hline 13. & & & 8 & 61,5 & 4 & 30,8 & 1 & 7,7 & & & 3,54 & 0,66 \\
\hline 14. & 4 & 30,8 & 7 & 53,8 & 2 & 15,4 & & & & & $4,15 * *$ & 0,689 \\
\hline 15. & 8 & 61,5 & 5 & 38,5 & & & & & & & $4,62 * *$ & 0,506 \\
\hline 16. & 8 & 61,5 & 5 & 38,5 & & & & & & & $4,62 * *$ & 0,506 \\
\hline 17. & & & 9 & 69,2 & 4 & 30,8 & & & & & 3,69 & 0,48 \\
\hline 18. & & & 10 & 76,9 & 1 & 7,7 & 2 & 15,4 & & & 3,62 & 0,768 \\
\hline 19. & & & 7 & 53,8 & 5 & 38,5 & 1 & 7,7 & & & 3,46 & 0,66 \\
\hline 20. & 3 & 23,1 & 10 & 76,9 & & & & & & & $4,23 * *$ & 0,439 \\
\hline 21. & & & & & 4 & 30,8 & 9 & 69,2 & & & $2,31 * *$ & 0,48 \\
\hline 22. & & & 5 & 38,5 & 4 & 30,8 & 4 & 30,8 & & & 3,08 & 0,862 \\
\hline 23. & & & 3 & 23,1 & 5 & 38,5 & 4 & 30,8 & 1 & 7,7 & $2,77 *$ & 0,927 \\
\hline 24. & 2 & 15,4 & 7 & 53,8 & 2 & 15,4 & 2 & 15,4 & & & 3,69 & 0,947 \\
\hline 25. & & & & & 5 & 38,5 & 7 & 53,8 & 1 & 7,7 & $2,31 * *$ & 0,63 \\
\hline 26. & 3 & 23,1 & 10 & 76,9 & & & & & & & $4,23 * *$ & 0,439 \\
\hline 27. & 5 & 38,5 & 6 & 46,2 & 1 & 7,7 & 1 & 7,7 & & & $4,15 * *$ & 0,899 \\
\hline 28. & & & & & & & 8 & 61,5 & 5 & 38,5 & $1,62 * *$ & 0,506 \\
\hline 29. & & & 1 & 7,7 & 8 & 61,5 & 2 & 15,4 & 2 & 15,4 & $2,62 * * *$ & 0,87 \\
\hline 30. & & & & & & & 8 & 61,5 & 5 & 38,5 & $1,62 * *$ & 0,506 \\
\hline
\end{tabular}

Tablo 3 ve Ek 1'de görüldüğü gibi, 15. sırada yer alan "Oyun ve etkinliklerde kaybetmeye ve kazanmaya ilişkin uygun davranışlar sergiler." (K15) kazanımı ile 16. sırada yer alan "Oyun ve etkinliklerde bireysel farklılıklara duyarlı olur.” (K16) kazanımının gerçekleşebilme düzeyine ilişkin öğretmen görüşlerinin aritmetik ortalaması $\overline{\mathrm{X}}=4,62$ 'dir. Aritmetik ortalaması "Çok Olumlu" puan aralığında değerlendirilen bu kazanımların gerçekleşebilme durumları "Tamamen/En Üst Düzey Yeterlik" şeklinde yorumlanabilir.

28. sırada yer alan "Yakın çevresine ait halk danslarını tanır." (K28) kazanımı ile 30. sırada yer alan "Olimpik kavramları bilir." (K30) kazanımının gerçekleşebilme düzeyine ilişkin öğretmen görüşlerinin aritmetik ortalaması $\overline{\mathrm{X}}=1,62$ 'dir. Aritmetik ortalaması "Çok Olumsuz" puan aralığında değerlendirilen bu kazanımların gerçekleşebilme durumları ise "Hiç/Yetersiz" şeklinde yorumlanabilir.

\section{2. İkinci Alt Probleme İlişkin Bulgular}

6. sınıf beden eğitimi ve spor dersi öğretim programı kazanımlarının gerçekleşebilme 
düzeylerine ilişkin betimsel istatistik dağılımları Tablo 4 ve Ek 2'den yararlanılarak aşağıda verilmiştir.

Tablo 4: 6. Sınıf Kazanımlarının Gerçekleșebilme Düzeylerine İlişkin Betimsel İstatistik Dağılımları

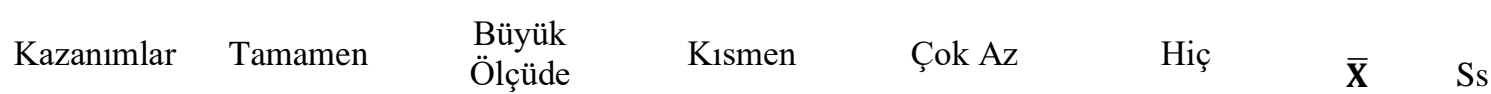

\begin{tabular}{|c|c|c|c|c|c|c|c|c|c|c|c|c|}
\hline Madde No & $\mathrm{n}$ & $\%$ & $\mathrm{n}$ & $\%$ & $\mathrm{n}$ & $\%$ & $\mathrm{n}$ & $\%$ & $\mathrm{n}$ & $\%$ & & \\
\hline 1. & & & 7 & 53,8 & 5 & 38,5 & 1 & 7,7 & & & 3,46 & 0,66 \\
\hline 2. & & & & & & & 4 & 30,8 & 9 & 69,2 & $1,62^{*}$ & 0,961 \\
\hline 3. & 1 & 7,7 & 9 & 69,2 & 1 & 7,7 & 2 & 15,4 & & & 3,69 & 0,855 \\
\hline 4. & & & & & & & & & 13 & 100 & $1,00 *$ & 0 \\
\hline 5. & & & 1 & 7,7 & 4 & 30,8 & 6 & 46,2 & 2 & 15,4 & 2,31 & 0,855 \\
\hline 6. & & & & & 6 & 46,2 & 7 & 53,8 & & & 2,46 & 0,519 \\
\hline 7. & & & & & 1 & 7,7 & 11 & 84,6 & 1 & 7,7 & $2,00 *$ & 0,408 \\
\hline 8. & & & 7 & 53,8 & 4 & 30,8 & 2 & 15,4 & & & 3,38 & 0,768 \\
\hline 9. & 1 & 7,7 & 8 & 61,5 & 4 & 30,8 & & & & & $3,77 *$ & 0,599 \\
\hline 10. & & & 7 & 53,8 & 4 & 30,8 & 1 & 7,7 & 1 & 7,7 & 3,31 & 0,947 \\
\hline 11. & & & 9 & 69,2 & 1 & 7,7 & 3 & 23,1 & & & 3,46 & 0,877 \\
\hline 12. & 6 & 46,2 & 6 & 46,2 & 1 & 7,7 & & & & & $4,38^{*}$ & 0,65 \\
\hline 13. & 6 & 46,2 & 7 & 53,8 & & & & & & & $4,46 * *$ & 0,519 \\
\hline 14. & 6 & 46,2 & 7 & 53,8 & & & & & & & $4,46 * *$ & 0,519 \\
\hline 15. & & & & & 4 & 30,8 & 6 & 46,2 & 3 & 23,1 & 2,08 & 0,76 \\
\hline 16. & & & 7 & 53,8 & 4 & 30,8 & 2 & 15,4 & & & 3,38 & 0,768 \\
\hline 17. & & & 8 & 61,5 & 4 & 30,8 & 1 & 7,7 & & & 3,54 & 0,66 \\
\hline 18. & & & 9 & 69,2 & 1 & 7,7 & 3 & 23,1 & & & 3,46 & 0,877 \\
\hline 19. & & & 8 & 61,5 & 4 & 30,8 & 1 & 7,7 & & & 3,54 & 0,66 \\
\hline 20. & & & 2 & 15,4 & 7 & 53,8 & 2 & 15,4 & 2 & 15,4 & 2,69 & 0,947 \\
\hline 21. & 1 & 7,7 & 5 & 38,5 & 4 & 30,8 & 3 & 23,1 & & & 3,31 & 0,947 \\
\hline 22. & & & 6 & 46,2 & 5 & 38,5 & 2 & 15,4 & & & 3,31 & 0,751 \\
\hline 23. & & & 5 & 38,5 & 5 & 38,5 & 3 & 23,1 & & & 3,15 & 0,801 \\
\hline 24. & & & 7 & 53,8 & 4 & 30,8 & 2 & 15,4 & & & 3,38 & 0,768 \\
\hline 25. & & & 5 & 38,5 & 3 & 23,1 & 5 & 38,5 & & & 3 & 0,913 \\
\hline 26. & 2 & 15,4 & 9 & 69,2 & 1 & 7,7 & 1 & 7,7 & & & $3,92^{*}$ & 0,76 \\
\hline 27. & 3 & 23,1 & 7 & 53,8 & 3 & 23,1 & & & & & $4,00^{*}$ & 0,707 \\
\hline 28. & & & & & 2 & 15,4 & 7 & 53,8 & 4 & 30,8 & $1,85^{*}$ & 0,689 \\
\hline 29. & & & & & & & 9 & 69,2 & 4 & 30,8 & $1,69 *$ & 0,48 \\
\hline 30. & & & 1 & 7,7 & 5 & 38,5 & 6 & 46,2 & 1 & 7,7 & 2,46 & 0,776 \\
\hline
\end{tabular}

Tablo 4 ve Ek 2'de görüldüğü gibi, 13. sırada yer alan "Sporlara hazırlayıcı oyun ve etkinliklerde başkalarının haklarına saygı gösterir." (K13) kazanımı ile 14. sırada yer alan "Sporlara hazırlayıcı oyun ve etkinliklerde bireysel farklılığı olanlarla çalışmaya gönüllü olur." (K14) kazanımının gerçekleşebilme düzeyine ilişkin öğretmen görüşlerinin aritmetik ortalaması $\overline{\mathrm{X}}=4,46$ 'dır. Aritmetik ortalaması "Çok Olumlu" puan aralığında değerlendirilen bu kazanımların gerçekleşebilme durumları "Tamamen/En Üst Düzey Yeterlik” şeklinde yorumlanabilir.

4. sırada yer alan "Su sporları/etkinlikleri ile ilgili hareket becerileri sergiler." (K4) kazanımının gerçekleşebilme düzeyine ilişkin öğretmen görüşlerinin aritmetik ortalaması $\overline{\mathrm{X}}=1.00$ 'dir. Aritmetik ortalaması "Çok Olumsuz" puan aralığında değerlendirilen bu kazanımın gerçekleşebilme durumu "Hiç/Yetersiz" şeklinde yorumlanabilir. 


\section{Üçüncü Alt Probleme İlişkin Bulgular}

7. sınıf beden eğitimi ve spor dersi öğretim programı kazanımlarının gerçekleşebilme düzeylerine ilişkin betimsel istatistik dağılımları Tablo 5 ve Ek 3'ten yararlanılarak aşağıda verilmiştir.

Tablo 5: 7. Sınıf Kazanımlarının Gerçekleşebilme Düzeylerine İlişkin Betimsel İstatistik Dağılımları

$\begin{array}{llllllll}\text { Kazanımlar } & \text { Tamamen } & \begin{array}{c}\text { Büyük } \\ \text { Ölçüde }\end{array} & \text { Kısmen } & \text { Çok Az } & \text { Hiç } & \overline{\mathbf{X}} & \text { Ss }\end{array}$

\begin{tabular}{|c|c|c|c|c|c|c|c|c|c|c|c|c|}
\hline Madde No & $\mathrm{n}$ & $\%$ & $\mathrm{n}$ & $\%$ & $\mathrm{n}$ & $\%$ & $\mathrm{n}$ & $\%$ & $\mathrm{n}$ & $\%$ & & \\
\hline 1. & 1 & 7,7 & 11 & 84,6 & 1 & 7,7 & & & & & $4,00^{*}$ & 0,408 \\
\hline 2. & & & & & 1 & 7,7 & 3 & 23,1 & 9 & 69,2 & $1,69 *$ & 1,109 \\
\hline 3. & 1 & 7,7 & 9 & 69,2 & 2 & 15,4 & 1 & 7,7 & & & 3,77 & 0,725 \\
\hline 4. & & & & & & & & & 13 & 100 & $1,00 *$ & 0 \\
\hline 5. & & & & & 3 & 23,1 & 6 & 46,2 & 4 & 30,8 & $1,92 * *$ & 0,76 \\
\hline 6. & & & & & 3 & 23,1 & 9 & 69,2 & 1 & 7,7 & $2,15 * * * *$ & 0,555 \\
\hline 7. & & & 1 & 7,7 & 1 & 7,7 & 10 & 76,9 & 1 & 7,7 & $2,15 * * * *$ & 0,689 \\
\hline 8. & & & 10 & 76,9 & 3 & 23,1 & & & & & 3,77 & 0,439 \\
\hline 9. & & & 10 & 76,9 & 3 & 23,1 & & & & & 3,77 & 0,439 \\
\hline 10. & & & 11 & 84,6 & 1 & 7,7 & 1 & 7,7 & & & 3,77 & 0,599 \\
\hline 11. & 2 & 15,4 & 10 & 76,9 & 1 & 7,7 & & & & & $4,08 *$ & 0,494 \\
\hline 12. & 1 & 7,7 & 9 & 69,2 & 3 & 23,1 & & & & & $3,85 * * *$ & 0,555 \\
\hline 13. & 6 & 46,2 & 7 & 53,8 & & & & & & & $4,46^{*}$ & 0,519 \\
\hline 14. & 8 & 61,5 & 4 & 30,8 & 1 & 7,7 & & & & & $4,54 * *$ & 0,66 \\
\hline 15. & & & 11 & 84,6 & 2 & 15,4 & & & & & $3,85 * * *$ & 0,376 \\
\hline 16. & 7 & 53,8 & 6 & 46,2 & & & & & & & $4,54 * *$ & 0,519 \\
\hline 17. & & & & & 2 & 15,4 & 8 & 61,5 & 3 & 23,1 & $1,92 * *$ & 0,641 \\
\hline 18. & & & 9 & 69,2 & 3 & 23,1 & 1 & 7,7 & & & 3,62 & 0,65 \\
\hline 19. & & & & & 8 & 61,5 & 4 & 30,8 & 1 & 7,7 & 3,46 & 0,877 \\
\hline 20. & & & 8 & 61,5 & 4 & 30,8 & 1 & 7,7 & & & 3,54 & 0,66 \\
\hline 21. & & & 10 & 76,9 & 1 & 7,7 & 2 & 15,4 & & & 3,62 & 0,768 \\
\hline 22. & 2 & 15,4 & 7 & 53,8 & 3 & 23,1 & 1 & 7,7 & & & 3,77 & 0,832 \\
\hline 23. & & & 8 & 61,5 & 4 & 30,8 & 1 & 7,7 & & & 3,54 & 0,66 \\
\hline 24. & & & 2 & 15,4 & 3 & 23,1 & 7 & 53,8 & 1 & 7,7 & 2,46 & 0,877 \\
\hline 25. & & & 10 & 76,9 & 2 & 15,4 & 1 & 7,7 & & & 3,69 & 0,63 \\
\hline 26. & & & & & 3 & 23,1 & 9 & 69,2 & 1 & 7,7 & $2,15 * * *$ & 0,555 \\
\hline 27. & & & 3 & 23,1 & 4 & 30,8 & 6 & 46,2 & & & 2,77 & 0,832 \\
\hline 28. & & & 11 & 84,6 & 2 & 15,4 & & & & & $3,85 * * *$ & 0,376 \\
\hline 29. & & & 3 & 23,1 & 5 & 38,5 & 5 & 38,5 & & & 2,85 & 0,801 \\
\hline 30. & & & & & 3 & 23,1 & 5 & 38,5 & 5 & 38,5 & $1,85^{*}$ & 0,801 \\
\hline 31. & & & & & & & & 38,5 & & 61,5 & & \\
\hline
\end{tabular}

Tablo 5 ve Ek 3'te görüldüğü gibi, 14. sırada yer alan "Sporlara hazırlayıcı oyun ve etkinliklerde adil oyun anlayışına uygun davranır." (K14) kazanımı ile 16. sırada yer alan "Sporlara hazırlayıcı oyun ve etkinliklerde bireysel farklılığı olanlarla çalışmaya istekli olur." (K16) kazanımının gerçekleşebilme düzeyine ilişkin öğretmen görüşlerinin aritmetik ortalaması $\bar{X}=4,54$ 'tür. Aritmetik ortalaması "Çok Olumlu" puan aralığında değerlendirilen bu kazanımların gerçekleşebilme durumları "Tamamen/En Üst Düzey Yeterlik" şeklinde yorumlanabilir.

4. sırada yer alan "Su sporları/etkinlikleri ile ilgili hareket becerilerini geliştirir." (K4) kazanımının gerçekleşebilme düzeyine ilişkin öğretmen görüşlerinin aritmetik ortalaması 
$\overline{\mathrm{X}}=1.00$ 'dir. Aritmetik ortalaması "Çok Olumsuz" puan aralığında değerlendirilen bu kazanımın gerçekleşebilme durumu "Hiç/Yetersiz" şeklinde yorumlanabilir.

\section{Dördüncü Alt Probleme İliş̧kin Bulgular}

8. sınıf beden eğitimi ve spor dersi öğretim programı kazanımlarının gerçekleşebilme düzeylerine ilişkin betimsel istatistik dağılımları Tablo 6 ve Ek 4'ten yararlanılarak aşağıda verilmiștir.

Tablo 6: 8. Sınıf Kazanımlarının Gerçekleşebilme Düzeylerine İlişkin Betimsel İstatistik Dağglımları

$\begin{array}{llllllll}\text { Kazanımlar } & \text { Tamamen } & \begin{array}{c}\text { Büyük } \\ \text { Ölçüde }\end{array} & \text { Kısmen } & \text { Çok Az } & \text { Hiç } & \overline{\mathbf{X}} & \text { Ss }\end{array}$

\begin{tabular}{|c|c|c|c|c|c|c|c|c|c|c|c|c|}
\hline Madde No & $\mathrm{n}$ & $\%$ & $\mathrm{n}$ & $\%$ & $\mathrm{n}$ & $\%$ & $\mathrm{n}$ & $\%$ & $\mathrm{n}$ & $\%$ & & \\
\hline 1. & 1 & 7,7 & 10 & 76,9 & 2 & 15,4 & & & & & 3,92 & 0,494 \\
\hline 2. & 4 & 30,8 & 9 & 69,2 & & & & & & & $4,31 *$ & 0,48 \\
\hline 3. & 2 & 15,4 & 9 & 69,2 & 2 & 15,4 & & & & & 4 & 0,577 \\
\hline 4. & 6 & 46,2 & 6 & 46,2 & 1 & 7,7 & & & & & $4,38 * *$ & 0,65 \\
\hline 5. & 2 & 15,4 & 10 & 76,9 & 1 & 7,7 & & & & & 4,08 & 0,494 \\
\hline 6. & 3 & 23,1 & 10 & 76,9 & & & & & & & 4,23 & 0,439 \\
\hline 7. & & & 10 & 76,9 & 3 & 23,1 & & & & & 3,77 & 0,439 \\
\hline 8. & & & 9 & 69,2 & 4 & 30,8 & & & & & 3,69 & 0,48 \\
\hline 9. & & & 2 & 15,4 & 5 & 38,5 & 4 & 30,8 & 2 & 15,4 & $2,54 * *$ & 0,967 \\
\hline 10. & 1 & 7,7 & 11 & 84,6 & & & 1 & 7,7 & & & 3,92 & 0,641 \\
\hline 11. & 1 & 7,7 & 11 & 84,6 & & & 1 & 7,7 & & & 3,92 & 0,641 \\
\hline 12. & 10 & 76,9 & 3 & 23,1 & & & & & & & $4,77 *$ & 0,439 \\
\hline 13. & 1 & 7,7 & 10 & 76,9 & 2 & 15,4 & & & & & 3,92 & 0,494 \\
\hline 14. & 4 & 30,8 & 8 & 61,5 & 1 & 7,7 & & & & & 4,23 & 0,599 \\
\hline 15. & 3 & 23,1 & 10 & 76,9 & & & & & & & 4,23 & 0,439 \\
\hline 16. & 7 & 53,8 & 6 & 46,2 & & & & & & & $4,54 *$ & 0,519 \\
\hline 17. & & & 12 & 92,3 & 1 & 7,7 & & & & & 3,92 & 0,277 \\
\hline 18. & 3 & 23,1 & 8 & 61,5 & 2 & 15,4 & & & & & 4,08 & 0,641 \\
\hline 19. & 2 & 15,4 & 9 & 69,2 & 2 & 15,4 & & & & & 4 & 0,577 \\
\hline 20. & & & 10 & 76,9 & 3 & 23,1 & & & & & 3,77 & 0,439 \\
\hline 21. & 3 & 23,1 & 10 & 76,9 & & & & & & & 4,23 & 0,439 \\
\hline 22. & 9 & 69,2 & 4 & 30,8 & & & & & & & $4,69 *$ & 0,48 \\
\hline 23. & 2 & 15,4 & 8 & 61,5 & 3 & 23,1 & & & & & 3,92 & 0,641 \\
\hline 24. & 5 & 38,5 & 8 & 61,5 & & & & & & & $4,38 * *$ & 0,506 \\
\hline 25. & & & 9 & 69,2 & 3 & 23,1 & 1 & 7,7 & & & $3,62 * * *$ & 0,65 \\
\hline 26. & & & 9 & 69,2 & 3 & 23,1 & 1 & 7,7 & & & $3,62 * * *$ & 0,65 \\
\hline 27. & & & 5 & 38,5 & 7 & 53,8 & 1 & 7,7 & & & $\mathbf{3 , 3 1} * *$ & 0,63 \\
\hline 28. & 2 & 15,4 & 9 & 69,2 & 1 & 7,7 & 1 & 7,7 & & & 3,92 & 0,76 \\
\hline 29. & 2 & 15,4 & 8 & 61,5 & 2 & 15,4 & 1 & 7,7 & & & 3,85 & 0,801 \\
\hline 30. & & & 5 & 38,5 & 7 & 53,8 & 1 & 7,7 & & & $3,31 * *$ & 0,63 \\
\hline 31. & 2 & 15,4 & 6 & 46,2 & 4 & 30,8 & 1 & 7,7 & & & 3,69 & 0,855 \\
\hline 32. & 1 & 7,7 & 7 & 53,8 & 4 & 30,8 & 1 & 7,7 & & & $3,62 * * *$ & 0,768 \\
\hline 33. & & & 7 & 53,8 & 6 & 46,2 & & & & & $\mathbf{3 , 5 4} * *$ & 0,519 \\
\hline 34. & & & 1 & 7,7 & 5 & 38,5 & 7 & 53,8 & & & $2,54 * *$ & 0,66 \\
\hline 35. & & & & & 4 & 30,8 & 9 & 69,2 & & & $2,31^{*}$ & 0,48 \\
\hline 36. & & & & & 10 & 76,9 & 3 & 23,1 & & & 3,77 & 0,439 \\
\hline 37. & & & & & 7 & 53,8 & 6 & 46,2 & & & $3,54 * *$ & 0,519 \\
\hline
\end{tabular}


Tablo 6 ve Ek 4'te görüldüğü gibi, 12. sirada yer alan “Zihinsel ve bedensel engelin spor yapmaya engel olmadığını bilir.” (K12) kazanımının gerçekleşebilme düzeyine ilişkin öğretmen görüşlerinin aritmetik ortalaması $\overline{\mathrm{X}}=4,77$ 'dir. Aritmetik ortalaması "Çok Olumlu" puan aralığında değerlendirilen bu kazanımın gerçekleşebilme durumu "Tamamen/En Üst Düzey Yeterlik" şeklinde yorumlanabilir.

35. sırada yer alan "Hazırladığı fiziksel uygunluğunu geliştirecek programları uygular." (K35) kazanımının gerçekleşebilme düzeyine ilişkin öğretmen görüşlerinin aritmetik ortalaması $\overline{\mathrm{X}}=2.31$ 'dir. Aritmetik ortalaması "Olumsuz" puan aralığında değerlendirilen bu kazanımın gerçekleşebilme durumu "Çok Az/Alt Düzey Yeterlik" şeklinde yorumlanabilir.

\section{Genel Durum Değerlendirmesi}

Ortaokul beden eğitimi ve spor dersi öğretim programı kazanımlarının gerçekleşebilme düzeylerine ilişkin betimsel istatistik dağılımları Tablo 7 ve 8 'den yararlanılarak aşağıda verilmiştir.

Tablo 7: Kazanımlarının Gerçekleşebilme Düzeylerine İlişkin Betimsel İstatistik Dağılımları

\begin{tabular}{cccccc}
\hline KAZANIMLAR & $\mathbf{n}$ & Min. & Max. & $\overline{\mathbf{X}}$ & Ss \\
\hline 5. Sinıf & 13 & 74,00 & 110,00 & 97,08 & 10,70 \\
\hline 6. Sinıf & 13 & 68,00 & 114,00 & 92,54 & 14,20 \\
\hline 7. Sinıf & 13 & 68,00 & 99,00 & 86,23 & 9,42 \\
\hline 8. Sinıf & 13 & 105,00 & 151,00 & 130,77 & 12,27 \\
\hline Kisaltmalar: & n: Kişi Sayıs1, Min.: Minimum Puan, Max.: Maksimum Puan, $\overline{\mathbf{X}}$ : Aritmetik \\
& Ortalama, Ss: Standart Sapma \\
\hline
\end{tabular}

Tablo 8: Kazanımların Gerçekleşebilme Düzeylerine İlişkin Aritmetik Ortalamaların Değerlendirilme Aralıkları

\begin{tabular}{cccc}
\hline AODA & Minimum Puan & Ortanca Puan & Maksimum Puan \\
\hline 5. Sinıf & $30 \times 1.00=30.00$ & $30 \times 3.00=90.00$ & $30 \times 5.00=150.00$ \\
\hline 6. Sinıf & $30 \times 1.00=30.00$ & $30 \times 3.00=90.00$ & $30 \times 5.00=150.00$ \\
\hline 7. Sinıf & $31 \times 1.00=31.00$ & $31 \times 3.00=93.00$ & $31 \times 5.00=155.00$ \\
\hline 8. Sinıf & $37 \times 1.00=37.00$ & $37 \times 3.00=111.00$ & $37 \times 5.00=185.00$ \\
\hline Kisaltmalar: & AODA: Aritmetik Ortalamaların Değerlendirilme Aralıkları \\
\hline
\end{tabular}

Tablo 7 ve 8'de görüldüğü gibi, kazanımların gerçekleşebilme düzeylerini gösteren 5'li likert tipi ölçme araçlarından alınan en küçük puanın 68.00; en yüksek puanın ise 151.00 olduğu görülmektedir.

Kazanımların gerçekleşebilme düzeylerinin belirlenmesinde her bir sınıf bazında ölçme aracına ait ortanca puan ile beden eğitimi ve spor öğretmenlerinin sınıflar bazında ölçme araçlarından aldıkları puan ortalamalarının karşılaştırılması yoluna gidilmiştir.

Bu doğrultuda, 30 maddelik 5. sınıf kazanımlarının yer aldığ ölçme aracından alınabilecek minimum puan $(30 \times 1.00) 30.00$, ortanca puan $(30 \times 3.00)$ 90.00, maksimum puan ise $(30 \times 5.00)$ 150.00 olarak belirlenmiştir. Beden eğitimi ve spor öğretmenlerinin 5. sınıf kazanımların gerçekleşebilme durumlarını gösteren ölçme aracından aldıkları puanların aritmetik ortalaması (97.08) belirlenen ortanca puanına (90.00) yakın bir değerde olduğu için 5. sınıf kazanımlarının gerçekleşebilme durumlarını "orta düzey yeterlik" şeklinde yorumlayabiliriz.

30 maddelik 6. sınıf kazanımlarının yer aldığı ölçme aracından alınabilecek minimum puan (30x1.00) 30.00, ortanca puan (30x3.00) 90.00, maksimum puan ise (30x5.00) 150.00 olarak belirlenmiştir. Beden eğitimi ve spor öğretmenlerinin 6. sınıf kazanımların gerçekleşebilme durumlarını gösteren ölçme aracından aldıkları puanların aritmetik ortalaması (92.54) belirlenen 
ortanca puanına (90.00) yakın bir değerde olduğu için 6. sınıf kazanımlarının gerçekleşebilme durumlarını "orta düzey yeterlik" şeklinde yorumlayabiliriz.

31 maddelik 7. sınıf kazanımlarının yer aldığ ölçme aracından alınabilecek minimum puan (31x1.00) 31.00, ortanca puan $(31 \times 3.00)$ 93.00, maksimum puan ise $(31 \times 5.00) 155.00$ olarak belirlenmiştir. Beden eğitimi ve spor öğretmenlerinin 7. sınıf kazanımların gerçekleşebilme durumlarını gösteren ölçme aracından aldıkları puanların aritmetik ortalaması (86.23) belirlenen ortanca puanına (93.00) yakın bir değerde olduğu için 7. sınıf kazanımlarının gerçekleşebilme durumlarını "orta düzey yeterlik" şeklinde yorumlayabiliriz.

37 maddelik 8. sınıf kazanımlarının yer aldığ (37x1.00) 37.00, ortanca puan $(37 \times 3.00) 111.00$, maksimum puan ise $(37 \times 5.00) 185.00$ olarak belirlenmiştir. Beden eğitimi ve spor öğretmenlerinin 8. sınıf kazanımların gerçekleşebilme durumlarını gösteren ölçme aracından aldıkları puanların aritmetik ortalaması (130.77) belirlenen ortanca puanına (111.00) yakın bir değerde olduğu için 8. sınıf kazanımlarının gerçekleşebilme durumlarını "orta düzey yeterlik" şeklinde yorumlayabiliriz.

Ancak, aritmetik ortalama gibi merkezi eğilim ölçülerinin kullanıldığı hesaplamalarda yakın ya da aynı değerlerin bulunması durumunda dahi, hesaplamanın yapıldığ gruplar birbirinden çok farklı olabilmektedir. Bir gruptaki aritmetik ortalamayı hesaplamada kullanılan birim puan dağılımlarının birbirinden çok farklı olabilmesi nedeniyle dağılım ölçütlerinden biri olan standart sapmanın da dikkate alınması daha net sonuçlar alınabilmesi ve birim puanlar arasındaki farklılaşma miktarının belirlenebilmesi açısından oldukça önemlidir (Frankel ve Wallen'den aktaran Demirel, Sadi ve Dağyar, 2016). Bu nedenle, kazanımların gerçekleşebilme durumlarına ilişkin her bir sınıf ölçeğinin değişim katsayıları da hesaplanmıştır. Değişim katsayısı standart sapmanın aritmetik ortalamaya bölümünün 100 ile çarpımı $\left(V=\frac{S S}{\bar{x}} \times 100\right)$ ile elde edilmekte ve ölçeklerden elde edilen puanların homojen ya da heterojen nasıl bir dağılım gösterdiklerini ortaya çıarmaktadır (Spiegel'den aktaran Büyüköztürk, Kılıç Çakmak, Akgün, Karadeniz ve Demirel, 2016; Frankel ve Wallen'den aktaran Demirel, Sadi ve Dağyar, 2016). Tek bir grubun ilgilenilen değişken açısından homojen olup olmadığının kararlaştırılmasında \%50 sınır değeri ölçüt olarak kabul edilirken; değişim katsayısının \%50'den küçük olması durumunda grubun homojen, \%50'den büyük olması durumunda ise grubun heterojen olduğu yorumu yapılabilir (Saraçbaşı, Karaağaoğlu ve Saka'dan aktaran Büyüköztürk, Kılıç Çakmak, Akgün, Karadeniz ve Demirel, 2016). Başka bir deyişle, değişim katsayısı ne kadar küçük çıkarsa, birim değerlerinin ortalama değere daha yakın olduğu ve homojen bir dağılım gösterdikleri sonucuna varılabilir (Demirel, Sadi ve Dağyar, 2016). Bu doğrultuda, sınıflar bazında kazanımların gerçekleșebilme durumlarına ilișkin ölçme araçlarının değişim katsayıları 5. sınıf \%11.02, 6. sınıf \%15.34, 7. sınıf \%10.92 ve 8. sınıf \%9.38 olarak hesaplanmıştır. Hesaplanan bu değişim katsayıları incelendiğinde, kazanımların gerçekleşebilme durumlarına ilişkin araştırmaya katılan öğretmen görüşlerinin homojen olduğu görülmektedir.

\section{Sonuç, Tartışma ve Öneriler}

Beden eğitimi ve spor dersi öğretim programı kazanımlarının Türkiye' deki görme engelliler ortaokullarında gerçekleşebilme düzeylerine ilişkin öğretmen görüşlerinin değerlendirildiği bu araştırmadan elde edilen bulgular 1şı̆̆ında, "Hareket Yetkinliğì" ve "Aktif ve Sağlıklı Yaşam" öğrenme alanlarına ilişkin kazandırılması hedeflenen davranışların gerçekleşebilme düzeylerinin "Orta Düzey Yeterlik" şeklinde olduğunu sonucuna ulaşılmıştır. Araşırma sonuçlarını her bir sınıf açısından ele alacak olursak:

5. sınıf beden eğitimi ve spor dersi öğretim programı kazanımlarının gerçekleşebilme durumlarına ilişkin betimsel istatistik verilerinin analizleri doğrultusunda, çok olumlu puan aralığında değerlendirilen "Oyun ve etkinliklerde kaybetmeye ve kazanmaya ilişkin uygun davranışlar sergiler.", "Oyun ve etkinliklerde bireysel farklılıklara duyarlı olur.", "Fiziksel 
etkinliklerin eğlenceli yönlerinin farkına varır.", "Millî bayramlar/belirli gün ve haftalar için hazırlanan etkinliklere katılır." kazanımlarının gerçekleşebilme durumlarının "En Üst Düzey Yeterlik" şeklinde olduğu sonucuna ulaşılırken; çok olumsuz puan aralığında değerlendirilen "Yakın çevresine ait halk danslarını tanır.", "Olimpik kavramları bilir." kazanımlarının gerçekleşebilme durumlarının ise "Yetersiz" şeklinde olduğu sonucuna ulaşılmıştır.

6. sınıf beden eğitimi ve spor dersi öğretim programı kazanımlarının gerçekleșebilme durumlarına ilişkin betimsel istatistik verilerinin analizleri doğrultusunda, çok olumlu puan aralığında değerlendirilen "Sporlara hazırlayıcı oyun ve etkinliklerde işbirliği yapmaya istekli olur.", "Sporlara hazırlayıcı oyun ve etkinliklerde başkalarının haklarına saygı gösterir.", "Sporlara hazırlayıcı oyun ve etkinliklerde bireysel farklılığı olanlarla çalışmaya gönüllü olur." kazanımlarının gerçekleşebilme durumlarının "En Üst Düzey Yeterlik" şeklinde olduğu sonucuna ulaşılırken; çok olumsuz puan aralığında değerlendirilen "Raket ve uzun saplı araçlarla yapılan sporlara hazırlayıcı oyunlardaki ve etkinliklerdeki hareket becerilerini sergiler.", "Su sporları/etkinlikleri ile ilgili hareket becerileri sergiler.", "Farklı kültürlere ait çocuk oyunlarını araştırır." kazanımlarının gerçekleşebilme durumlarının ise "Yetersiz" şeklinde olduğu sonucuna ulaşılmıştır.

7. sınıf beden eğitimi ve spor dersi öğretim programı kazanımlarının gerçekleşebilme durumlarına ilişkin betimsel istatistik verilerinin analizleri doğrultusunda, çok olumlu puan aralığında değerlendirilen "Sporlara hazırlayıcı oyun ve etkinliklerde işbirliğine dayalı davranışlar gösterir.", "Sporlara hazırlayııı oyun ve etkinliklerde adil oyun anlayışına uygun davranır.", "Sporlara hazırlayıcı oyun ve etkinliklerde bireysel farklılığı olanlarla çalışmaya istekli olur." kazanımlarının gerçekleşebilme durumlarının "En Üst Düzey Yeterlik" şeklinde olduğu sonucuna ulaşılırken; çok olumsuz puan aralığında değerlendirilen "Raket ve uzun saplı araçlarla yapılan sporlara hazırlayıcı oyun ve etkinliklerde hareket becerilerini artan bir doğrulukta sergiler.", "Su sporları/etkinlikleri ile ilgili hareket becerilerini geliştirir.", "Ülkemizin olimpiyat tarihini araştırır." kazanımlarının gerçekleşebilme durumlarının ise "Yetersiz" şeklinde olduğu sonucuna ulaşılmıştır.

8. sınıf beden eğitimi ve spor dersi öğretim programı kazanımlarının gerçekleşebilme durumlarına ilişkin betimsel istatistik verilerinin analizleri doğrultusunda, çok olumlu puan aralığında değerlendirilen "Seçili spor dallarını yaparken spor dalına özgü ilke ve kuralları uygular.", "Sportif etkinlikleri yaparken çevreye karşı duyarlı olur.", "Zihinsel ve bedensel engelin spor yapmaya engel olmadığını bilir.", "Sportif etkinliklerde başkalarının haklarına saygı gösterir.", "Bireysel farklılıkları olanlarla sportif etkinlik yapmaya değer verir.", "Kendisinin ve grubunun hedeflerine ulaşmak için işbirliği içinde olur.", "Seçili sportif etkinliklerle ilgili kavramları bilir.", "Araç-gereçleri ve alanlarını paylaşmaya değer verir.", "Sportif etkinliklere ilişkin düşüncelerini ifade eder.", "Sportif etkinliklere katılmaya, değer verir." kazanımlarının gerçekleşebilme durumlarının "En Üst Düzey Yeterlik" şeklinde olduğu sonucuna ulaşılırken; olumsuz puan aralığında değerlendirilen "Performansını analiz etmek için mekaniğin ilkelerini kullanır.", "Atatürk'ün, spora ve sporculara verdiği önemi araştırarak çıkarımlarda bulunur.", "Olimpiyat oyunlarının sosyal, kültürel ve ekonomik açıdan ülkelere sağladığı katkıları araştırarak yorumlar." kazanımlarının gerçekleşebilme durumlarının "Alt Düzey Yeterlik" şeklinde olduğu sonucuna ulaşılmıştır.

Son olarak yapılan genel durum değerlendirmesi doğrultusunda beden eğitimi ve spor öğretmenlerinin 5, 6, 7. ve 8. sınıf kazanımların gerçekleşebilme durumlarını gösteren ölçme araçlarından aldıkları puanların aritmetik ortalamaları (5. sınıf 97.08; 6. sinıf 92.54; 7. sınıf 86.23; 8 . sınıf 130.77) belirlenen ölçme aracı ortanca puanlarına (5. sınıf 90.00; 6. sınıf 90.00; 7. sinıf 93.00; 8. sınıf 111.00) yakın bir değerde olduğu için 5, 6, 7. ve 8. sınıf kazanımlarının gerçekleşebilme durumlarının "orta düzey yeterlik" şeklinde olduğu sonucuna ulaşılmıştır. Ancak, aritmetik ortalama gibi merkezi eğilim ölçülerinin kullanıldığı hesaplamalarda yakın ya da aynı değerlerin bulunması durumunda dahi hesaplamanın yapıldı ğı gruplar birbirinden çok farklı olabileceğinden daha net 
sonuçların alınabilmesi adına standart sapmanın da dikkate alınması büyük bir önem teşkil etmektedir. Bu nedenle, ölçümler arasındaki değişimin azlığı ya da çokluğu hakkında bilgi edinmek için kazanımların gerçekleşebilme durumlarına ilişsin her bir sınıfa ait ölçme aracının değişim katsayıları da hesaplanmıştır. Yapılan merkezi eğilim ve değişkenlik ölçümleri sonucunda ise kazanımların gerçekleşebilme durumlarına ilişkin araştırmaya katılan bütün öğretmen görüşlerinin “Orta Düzey Yeterlik” şeklinde homojen bir dağılım gösterdiği sonucuna varılmıştır. Bu durumun uygulanmakta olan öğretim programlarının olağan gelişim özellikleri gösteren öğrencilerin gelişim ve eğitim ihtiyaçları doğrultusunda hazırlanmış olması ve farklı gelişim özellikleri gösteren öğrencilere ilişkin hiçbir düzenlemenin yer almamasından kaynaklanmış olabileceği düşünülmektedir.

Ayrıca yapılan anket çalışmasının sonunda, araştırmaya katılan öğretmenlerden araştırma konusuna yardımcı olabileceklerini düşündükleri görüş ve önerilere yer verilmesi istenmiştir. Genel anlamda araştırmanın bu bölümünden elde edilen bulgular öğretim programlarının görme yetersizliğinden etkilenen öğrencilerin gelişimsel ve eğitimsel ihtiyaçlarını karşılayıcı nitelikte olmayışının; okul yönetimi, öğretmen ve velilerin beden eğitimi, spor ve bağımsız hareket dersine ilişkin olumsuz tutumlarının; yetersiz ders saatlerinin, araç-gereç ve fiziki alt yapı eksikliklerinin kazanımların gerçekleşebilme durumlarına olumsuz etki edebileceği şeklinde yorumlanmıştır. Bu bağlamda, araştırmaya katılan öğretmenlerin hareket eğitiminin yetersizlikten etkilenme gruplarına göre yapılandırılması ve farklı potansiyel, fiziksel ve/veya zihinsel özellik ve yeteneklere sahip çocukların gelişimsel ve eğitimsel ihtiyaçları doğrultusunda yeni bir işlevsel öğretim programının hazırlanması isteği ilgili alan yazındaki diğer araştırma bulgularıyla paralellik göstermektedir. İlgili alanyazında birçok çalışma ile aynı doğrultuda olan bu araştırma sonucundan da anlaşılacağı üzere farklı gelişimsel özellik ve yeteneklere sahip çocukların bir birey olarak ilgi, istek ve yeteneklerinin farkına varabilecekleri, hazırbulunuşluk düzeylerine uygun yeni, işlevsel bir öğretim programının önemi ve gerekliliği üzerinde yaygın bir görüş birliği vardır (Ayça, 2013; Çevrim, 2009; Demirci ve Toptaş Demirci, 2014; Duman, 2003; Ercan, 1991; Ertunç, 2008; Kayapınar ve Özüdoğru, 2010; Kaytaz, 2004; Kurtlar, 2009; Oral, Akyüz, Sindel ve Aydın, 2012; Smagulova, 2009; Terzioğlu, 2002; Top, 2007; Toptaş Demirci vd., 2014; Türk, 2007; Usta, 2010).

Farklı potansiyel, fiziksel ve/veya zihinsel yeteneklere sahip çocukların yetersiz eğitim sonucu öğrenme güçlükleri yaşamaları olası bir durum olup gelişim ve öğrenmeleri de aynı doğrultuda etkilenmektedir. Bu çocukların toplumsal normların gerektirdiği davranış örüntülerini kazanmaları ve akranları gibi öğrenip gelişmeleri, var olan program ögelerinde (hedef, içerik, öğrenme-öğretme süreci ve değerlendirme) değişiklikler ya da uyarlamalar yapılmasını gerektirmektedir (Cole, 2006; Fitzgerald, 2009; Grout vd., 2009; Lamichhane, 2015; Lavin, 2008; Ruebain ve Haines, 2011; Vickerman, 2007). Farklılıklar yerine farklılığın gelişim ve öğrenme üzerindeki etkilerine programın bu ögeleri dikkate alınarak bakıldığında olağan gelişim gösteren çocuklar için var olan eğitim programında farklı gelişim özellikleri gösteren bireyler için yapılması gereken değişiklikler açıklık kazanmaktadır. Ayrıca gelişim farklılıkları türüne göre özel eğitim okullarına yerleştirilen çocukların yetersizlikten etkilenme derecelerinin homojen olmaması gösterdikleri davranışların da homojen olamayacağının açık bir göstergesidir. $\mathrm{Bu}$ nedenle yetersizlikten etkilenme durumunun engele dönüşmesini önleyen bir anlayış çerçevesinde, özel eğitim okullarında uygulanan programları çocuğun programda yapabildiklerinden hareketle çocuğa göre uyarlanması bir zorunluluk haline gelmektedir (A. Turnbull vd., 2013; Cohen, 2009; Dubos ve Fromer, 2006; France, 2009; Gallahue, 1996; Özyürek, 2010; Swain vd., 2003).

Bilindiği üzere görme yetersizliğinden etkilenen öğrencilerin motor gelişimleri olağan gelişim gösteren öğrencilere göre farklılık gösterebilmektedir. Beden eğitimi ve spor dersi öğretim programları kazanımlarının olağan gelişim özellikleri gösteren öğrencilere göre hazırlanmış olması ve farklı gelişim özellikleri gösteren öğrencilerin bireysel ve eğitimsel ihtiyaçlarını karşılayıcı nitelikte olmayışı, farklı gelişim özellikleri gösteren öğrencilerin öğretim programlarındaki 
kazanımlara ulaşmasını güçleştirdiği ve dolayısıyla da eğitimde fırsat eşitliğinin önüne geçildiği düşünülmektedir. Kazanımlar belirlenirken görme yetersizliğinden etkilenen öğrencilerin gelişimsel özellik ve gereksinimlerinin dikkate alınmaması, bu öğrencilerin beden eğitimi, spor ve bağımsız hareket dersinde hedeflenen amaçlara etkili ve verimli bir şekilde ulaşmasını engellediği düşünülmektedir. Beden eğitimi ve spor dersi gibi yaşamla iç içe olan uygulamalı derslerin öğretim programlarını hazırlayan alan uzmanlarının teorideki hedeflerin yanı sıra öğretmen ve öğrencilerin uygulamadaki hedeflerini de dikkate almaları özel gereksinimleri olan öğrencilerin kazandırılması amaçlanan hedeflere ulaşmalarını kolaylaştıracağı düşünülmektedir.

\section{Kaynakça}

Arac1, H. (2006). Öğretmenler ve Öğrenciler İçin Okullarda Beden Eğitimi. Ankara: Nobel.

Ayça, M. (2013). Goalball Sporunun Görme Engelli Çocukların Fiziksel Performanslarına, Kendilerinin ve Ailelerinin Yaşam Doyumu ve Umutsuzluk Düzeyine Etkisi. Yüksek Lisans Tezi. Ondokuz Mayıs Üniversitesi Sağl1k Bilimleri Enstitüsü, Samsun.

Büyüköztürk, Ş., Çakmak, E. K., Akgün, Ö. E., Karadeniz, Ş. ve Demirel F. (2016). Bilimsel Araştirma Yöntemleri. Ankara: Pegem A Akademi.

Cohen, M. (2009). A Guide to Special Education Advocacy. London: Jessica Kingsley.

Cole, M. (2006). Education, Equality and Human Rights: Issues of Gender, Race, Sexuality, Disability and Social Class. New York: Routledge.

Creswell, J. W. (2017). Nitel, nicel ve karma yöntem yaklaşımları (Çev. Ed. S. B. Demir). Ankara: Eğiten Kitap.

Çalışkan, E., Pehlivan, A., İnal, S., Dane, Ş. ve Akar, S. (2006). Goalball Sporunun ve Hareket Eğitiminin Görme Engelli Çocukların Fiziksel Uygunluk Üzerine Etkilerinin Değerlendirilmesi. Atatürk Üniversitesi Beden Eğitimi ve Spor Bilimleri Dergisi, 8(3), 3-14.

Çebi, M. (2013). Farklı Engel Gruplarındaki Sporcuların Denge, Solunum Kapasitesi ve Reaksiyon Zamanlarının Karşılaştırılması. Doktora Tezi. Ondokuz Mayıs Üniversitesi Sağlık Bilimleri Enstitüsü, Samsun.

Çelik Kayapınar, F. ve Özüdoğru, E. (2010). Engelli Bireylerin Spor Yapma Durumları ile Anne ve Baba Eğitim Düzeyleri Arasındaki İlişki. Selçuk Üniversitesi Beden Eğitimi ve Spor Bilimleri Dergisi, 12(3), 179-184.

Çelik Kayapınar, F. ve Özüdoğru, E. (2010). Engelli Bireylerin Spor Yapma Durumları ile Anne ve Baba Eğitim Düzeyleri Arasındaki İlişki. Selçuk Üniversitesi Beden Eğitimi ve Spor Bilimleri Dergisi, 12(3), 179-184.

Çevrim, H. (2009). Engellilerde Beden Eğitimi ve Spor Dersinin Programdaki Yeri ve İşlenişinin Değerlendirilmesi. Yüksek Lisans Tezi. Fırat Üniversitesi Sağlık Bilimleri Enstitüsü, Elazığ.

Çocuk Haklarına Dair Sözleşme. (1995). T.C. Resmi Gazete, 22184, 27 Ocak 1995. http://www.resmigazete.gov.tr/arsiv/22184.pdf sayfasından erişilmiştir.

Dağl1, A. (2007). Eğitimin Hukuksal Temelleri. Ö. Demirel ve Z. Kaya (Ed.), Eğitim Bilimine Giriş (s. 205-231). Ankara: Pegem.

Demirci, N. ve Toptaş Demirci, P. (2014). Özel Eğitime Gereksinim Duyan Öğrencilerin Oyun ve Fiziki Etkinlikler Dersinde Elde Ettikleri Kazanımların İncelenmesi. İnönü Üniversitesi, Beden Eğitimi ve Spor Bilimleri Dergisi, 1(1), 25-34. 
http://dergipark.ulakbim.gov.tr/inubesyo/article/download/5000003927/pdf_2 sayfasindan erişilmiştir.

Demirel, M., Sadi, Ö. ve Dağyar, M. (2016). Fen Bilimleri Öğ retmenlerinin Yaşam Boyu Öğrenme Yeterliklerinin İncelenmesi (Karaman İli Örneği). Pegem Ĕgitim ve Öğretim Dergisi, 6(1), 19-40. http://dx.doi.org/10.14527/pegegog.2016.002.

Doğan, H. Y. (2010). Afyonkarahisar İlinde Özel Eğitim Kurumlarında 9-11 Yaşlarındaki Engellilerde 12 Haftalı Düzenli Egzersizlerin Bazı Fiziksel ve Fizyolojik Parametreleri Üzerine Etkilerinin Araştırılması. Yüksek Lisans Tezi. Afyon Kocatepe Üniversitesi Sağlık Bilimleri Enstitüsü, Afyonkarahisar.

Dubos, L. ve Fromer, J. (2006). A Parent's Guide to Special Education in New York City and the Metropolitan Area. New York: Teacher College.

Duman, S. (2003). Özel Ĕ̌itim Sinıflarında Uygulanan Beden Ĕ̈itimi Dersi Öğretim Programının Öğretmen Görüşleriyle Değerlendirilmesi. Yüksek Lisans Tezi. Selçuk Üniversitesi Sağl1k Bilimler Enstitüsü, Konya.

Ercan, M. M. (1991). Federal Almanya ve Türkiye'de Özel Eğitim Sistemlerinin Karşılaştırmalı Olarak Incelenmesi. Yüksek Lisans Tezi. Gazi Üniversitesi Sosyal Bilimler Enstitüsü, Ankara.

Ertunç, E. N. (2008). Kaynaştırma Eğitimi Uygulanan İlköğretim İkinci Kademede Görev Alan Beden Ĕgitimi Öğretmenlerinin Kaynaştırma Ĕgitimi Hakkındaki Bilgi Düzeylerinin ve Sınıflarındaki Engelli Öğrencilere Bakış Açılarının Değerlendirilmesi. Yüksek Lisans Tezi. Gazi Üniversitesi Eğitim Bilimleri Enstitüsü, Ankara.

Fitzgerald, H. (2009). Disability and Youth Sport. New York: Routledge.

France, R. C. (2009) Physical Education and Sport Science. The United States of America: Delmar.

Gallahue, D. L. (1996). Developmental Physical Education for Today's Children. The United States of America: Brown \& Benchmark.

Grout, H., Long, G. ve Marshallsay, P. (2009). İmproving Teaching and Learning in Physical Education. H. Grout \& G. Long (Eds.), Inclusion in physical education lessons through differentiated teaching approaches and removing barriers to learning (pp. 103-141). New York: Open University.

İnsan Hakları Evrensel Beyannamesi. (1949). T. C. Resmi Gazete, 7217, 27 May1s 1949. http://www.resmigazete.gov.tr/arsiv/7217.pdf sayfasından erişilmiştir.

Karasar, N. (2014). Bilimsel Araştırma Yöntemi. Ankara: Nobel.

Kaytaz, K. (2004). Normal ve Engelli Çocuklara Ë̆itim Veren Okullarda Çalış an Beden Ĕ̈ itimi Öğ retmenlerinin $\dot{I}$ ş Dönüş ümü Karş ılaş tırılması. Yüksek Lisans Tezi. Sakarya Üniversitesi Sosyal Bilimler Enstitüsü, Sakarya.

Kılıçoğlu, M. (2006). Anasınıfi, Hazırlık ve İlköğretim Birinci Sinıfinda Okuyan Görme Engelli Ögrencilerin Oyunlarının Değerlendirilmesi: Karşılaştırmalı Bir Araştırma. Yüksek Lisans Tezi. Selçuk Üniversitesi Sosyal Bilimler Enstitüsü, Konya.

Kızar, O. (2012). Farklı Branşlardaki Görme Engelli Sporcuların Yalnızlı Düzeylerinin Karşılaştırılması. Yüksek Lisans Tezi. Fırat Üniversitesi Sağlık Bilimleri Enstitüsü, Elazığ. 
Konar, N. ve Pepe, K. (2003). Rehabilitasyon - Engelliler Sporu ve Paralimpikler. Ístanbul Üniversitesi Spor Bilimleri Dergisi, 11(3), 162- 166. http://sporbilimleri.istanbul.edu.tr/wpcontent/uploads/2014/06/33.- MAKALE_Layout-1.pdf sayfasından erişilmiştir.

Konar, N. ve Pepe, K. (2003). Rehabilitasyon - Engelliler Sporu ve Paralimpikler. Ístanbul Üniversitesi Spor Bilimleri Dergisi, 11(3), 162- 166. http://sporbilimleri.istanbul.edu.tr/wpcontent/uploads/2014/06/33.- MAKALE_Layout-1.pdf sayfasından erişilmiştir.

Konar, N. ve Yıldıran, İ. (2012). Engelliler için Beden Eğitimi ve Spor Öğretmenliği Gereksinimi ve Bir Program Modeli. Selçuk Üniversitesi Beden Eğitimi ve Spor Bilim Dergisi, 14(2), 208216. http://www.acarindex.com/dosyalar/makale/acarindex- 1423931801.pdf sayfasından erişilmiştir.

Koparan, Ş. (2003). Özel İhtiyaçları Olan Çocuklarda Spor. Uludağ Üniversitesi Ĕ̆ itim Fakültesi Dergisi, 17(1), 153-160. http://uludag.dergipark.gov.tr/download/article- file/153222 sayfasından erişilmiştir.

Kurtlar, C. (2009). Engelli Okullarında Görev Yapan Beden Eğitimi Öğretmenlerinin Tükenmişlik Düzeyleri Üzerine Bir Araştırma. Yüksek Lisans Tezi. Sakarya Üniversitesi Sosyal Bilimler Enstitüsü, Sakarya.

Lamichhane, K. (2015). Disability Education and Employment in Developing Countries. İndia: Cambridge University.

Lavin, J. (2008). Creative Approaches to Physical Education: Helping Children to Achieve Their True Potential. New York: Routledge.

MEB (2006). İlköğretim Beden Eğitimi Dersi Öğretim Programı. http://ttkb.meb.gov.tr/program2.aspx?islem=1\&kno=19 sayfasından erişilmiştir.

MEB (2013). Beden Eğitimi ve Spor Dersi Öğretim Program1. http://ttkb.meb.gov.tr/program2.aspx?islem=1\&kno=223 sayfasından erişilmiştir.

Milli Eğitim Temel Kanunu. (1973). T. C. Resmi Gazete, 14574, 24 Haziran 1973. http://www.resmigazete.gov.tr/arsiv/14574.pdf sayfasından erişilmiştir.

Muratl1, S. (2007). Antrenman Bilimi Yaklaşımıyla Çocuk ve Spor. Ankara: Nobel.

Oral, A., Akyüz G., Sindel, D. ve Aydın, R. (2012). Dünya Engellilik Raporu: Harekete Çağrı. Türkiye Fiziksel Tlp ve Rehabilitasyon Dergisi, 58(3), 255-258. http://www.ftrdergisi.com/uploads/sayilar/208/buyuk/255-2581.pdf sayfasından erişilmiştir.

Özer, D. (2005). Engelliler için Beden Eğitimi ve Spor. Ankara: Nobel.

Özyürek, M. (2010). Bireyselleştirilmiş Eğitim Programı Geliştirme ve Temelleri. Ankara: Kök.

Ruebain D. ve Haines, S. (2011). Education, Disability and Social Policy. Great Britain: Policy.

Sarpkaya, R. (2008). Türk Eğitim Sisteminin Amaçları ve Temel İlkeleri. R. Sarpkaya (Ed.), Türk Eğitim Sistemi ve Okul Yönetimi (s.1-21). Ankara: An1.

Smagulova L. (2009). Özel Eğitim ve Rehabilitasyon Hizmetleri Yönetimi. Yüksek Lisans Tezi. Uludağ Üniversitesi Sosyal Bilimler Enstitüsü, Bursa.

Sönmez, V. ve Alacapınar, F. G. (2014). Örneklendirilmiş bilimsel araştırma yöntemleri. Ankara: Anı Yayıncilik.

Swain, J., French, S. ve Cameron, C. (2003). Controversial İssues in a Disabling Society. London: Open University. 
Terzioğlu, E. A. (2002). Engelliler Spor Eğitiminde Beden Eğitimi Öğretmenlerinin Kategorik Görevleri. Erzincan E $\breve{g}$ itim Fakültesi Dergisi, 4(1). http://eefdergi.erzincan.edu.tr/article/view/1006000129/1006000053 sayfasından erişilmiştir.

Top, C. E. (2007). 14 Haftalık Fiziksel Aktivite Programının 10 -12 Yaş Görme Engelli Çocuklar Üzerine Etkileri. Yüksek Lisans Tezi. Akdeniz Üniversitesi Sağlık Bilimleri Enstitüsü, Antalya.

Toptaş Demirci, P., Çınar, İ. ve Demirci, N. (2014). Sınıf Öğretmenlerinin Özel Eğitime Gereksinim Duyan Öğrencilerde Beden Eğitimi Dersi Programında ve Kaynaştırma Eğitiminden Kaynaklanan Sorunların İncelenmesi. Uluslararası Türk Eğitim Bilimleri Dergisi, 2(2), 136150. http://uteb.gop.edu.tr/Makaleler/555676518_10- pervin\%20Toptaş\%20demirci.pdf sayfasından erişilmiştir.

Tuç, E. Ö. (2010). Görme Engelli Bireylerin Sosyalleşme Sürecine Sporun Etkisi. Yüksek Lisans Tezi. Gazi Üniversitesi Eğitim Bilimleri Enstitüsü, Ankara.

Turnbull, A., Turnbull, R., Wehmeyer, M. L. ve Shogren, K. A. (2013). Exceptional Lives: Special Education in Today's Schools. New Jersey: Pearson.

Tüfekçioğlu, U. (Ed.). (2003). Çocukta Hareket, Oyun Gelişimi ve Öğretimi. Eskişehir: Anadolu Üniversitesi.

Türk, E. (2007). Spor Takımlarına Katılan ve Katılmayan Görme Engelli Öğrencilerin Benlik Saygılarının Değerlendirilmesi. Yüksek Lisans Tezi. Çukurova Üniversitesi Sosyal Bilimler Enstitüsü, Adana.

Türkiye Cumhuriyeti Anayasası. (1982). T. C. Resmi Gazete, 17844, 20 Ekim 1982. http://www.resmigazete.gov.tr/arsiv/17844.pdf sayfasından erişilmiştir.

UNICEF (2016a). Çocuk Haklarına Dair Sözleşme. http://www.unicef.org/turkey/crc/_cr23b.html sayfasından erişilmiştir.

UNICEF (2016b). İnsan Haklar1 Evrensel Beyannamesi. http://www.unicef.org/turkey/udhr/_gi17.html://sayfasından erişilmiştir.

Uslu, A. ve Shakouri, N. (2012). Engelli Çocuklara Dost Oyun Alanı ve Dıı̧ Mekan Tasarımı. Erciyes Ü niversitesi Fen Bilimleri Enstitü sü Dergisi, 28(5), 367-375. http://www.as- koop.org/wpcontent/uploads/2015/11/FULL.pdf sayfasından erişilmiştir.

Usta, A. (2010). Ankara İlinde Engelli Okullarında Çalışan Beden Eğitimi Öğretmenlerinin Karşılaş̧tıkları Eğitim Güçlükleri. Yüksek Lisans Tezi. Gazi Üniversitesi Sağlık Bilimleri Enstitüsü, Ankara.

Vickerman, P. (2007). Teaching Physical Eduvation to Children with Special Educational Needs. The United States of America: Routledge. 


\section{EKLER}

Ek 1.

5. Sınıf Kazanımlarının Gerçekleşebilme Düzeylerine Göre Sınıflandırılması

\begin{tabular}{|c|c|}
\hline En Üst Düzey Yeterlik & $\begin{array}{l}\text { K15. Oyun ve etkinliklerde kaybetmeye ve kazanmaya ilişkin uygun } \\
\text { davranışlar sergiler. } \\
\text { K16. Oyun ve etkinliklerde bireysel farklılıklara duyarlı olur. } \\
\text { K20. Fiziksel etkinliklerin eğlenceli yönlerinin farkına varır. } \\
\text { K26. Millî bayramlar/belirli gün ve haftalar için hazırlanan etkinliklere } \\
\text { katılır. }\end{array}$ \\
\hline Üst Düzey Yeterlik & $\begin{array}{l}\text { K1. Yer değiştirme hareketlerinin farklı uygulamalarını gösterir. } \\
\text { K3. Vücudun farklı bölümlerini ve farklı ekipmanları kullanarak nesne } \\
\text { kontrolü gerektiren hareketleri yapar. } \\
\text { K8. Oyun ve etkinliklerde kullandı̆̆ı temel hareket kavramlarını açıklar. } \\
\text { K10. Oyunlara ve etkinliklere katılımda güçlü ve geliştirilmesi gereken } \\
\text { yönlerinin farkına varır. } \\
\text { K9. Oyun ve etkinliklerde beceri gelişimi için kendi kontrolünde olan } \\
\text { faktörleri bilir. } \\
\text { K11. Oyun ve etkinliklerde belirlenen kural ve yönergeleri uygular. } \\
\text { K12. Oyun ve etkinliklerde zamanı etkili kullanmanın önemini fark eder. } \\
\text { K13. Oyun ve etkinliklerde farklı iletişim yollarını kullanır. } \\
\text { K14. Oyun ve etkinliklerde işbirliğinin önemini kavrar. } \\
\text { K17. Oyun ve etkinliklerde kendisinin ve arkadaşlarının performanslarını } \\
\text { değerlendirir. } \\
\text { K18. Oyun ve etkinliklerde hücum ve savunma stratejilerini/taktiklerini } \\
\text { gösterir. } \\
\text { K19. Fiziksel etkinliklere düzenli olarak katılır. } \\
\text { K24. Fiziksel etkinliklerde kendisinin ve başkalarının sağlık ve } \\
\text { güvenliğine etki eden durumları açıklar. } \\
\text { K27. Atatürk'ün sporla ilgili söylediği sözleri açıklar. }\end{array}$ \\
\hline Orta Düzey Yeterlik & $\begin{array}{l}\text { K2. Dengeleme gerektiren hareketleri farklı hız ve seviyelerde uygular. } \\
\text { K4. Birleştirilmiş hareket becerilerini çeşitli oyun ve etkinliklerde } \\
\text { gösterir. } \\
\text { K5. Temel cimnastik hareketlerini yapar. } \\
\text { K6. Verilen ritim ve müziğe uygun dans adımlarını uygular. } \\
\text { K22. Katıldı̆ı fiziksel etkinliklerin, fiziksel uygunluğuna olan etkilerini } \\
\text { açıklar. } \\
\text { K23. Fiziksel etkinliklerde ne zaman ve nasıl beslenmesi gerektiğini } \\
\text { açıklar. } \\
\text { K29. Geleneksel çocuk oyunlarını tanır. }\end{array}$ \\
\hline Alt Düzey Yeterlik & $\begin{array}{l}\text { K7. Yakın çevresine ait halk danslarını uygular. } \\
\text { K21. Fiziksel etkinlik düzeyini çeşitli yöntemler kullanarak ölçer. } \\
\text { K25. Fiziksel etkinliklerde ilkyardımın genel amaçlarını ve } \\
\text { uygulamalarını bilir. }\end{array}$ \\
\hline Yetersiz & $\begin{array}{l}\text { K28. Yakın çevresine ait halk danslarını tanır. } \\
\text { K30. Olimpik kavramları bilir. }\end{array}$ \\
\hline
\end{tabular}

Turkish Studies - Social, 15(3) 
Ek 2.

6. Sınıf Kazanımlarının Gerçekleşebilme Düzeylerine Göre Sınıflandırılması

\begin{tabular}{|c|c|}
\hline En Üst Düzey Yeterlik & $\begin{array}{l}\text { K12. Sporlara hazırlayıcı oyun ve etkinliklerde işbirliği yapmaya istekli } \\
\text { olur. } \\
\text { K13. Sporlara hazırlayıcı oyun ve etkinliklerde başkalarının haklarına } \\
\text { saygı gösterir. } \\
\text { K14. Sporlara hazırlayıcı oyun ve etkinliklerde bireysel farklılığı } \\
\text { olanlarla çalışmaya gönüllü olur. }\end{array}$ \\
\hline Üst Düzey Yeterlik & $\begin{array}{l}\text { K1. Bireysel ve takım sporlarına hazırlayıcı oyun ve etkinliklerde } \\
\text { birleştirilmiş hareket becerileri sergiler. } \\
\text { K3. Doğada yapılan etkinliklerle ilgili becerileri sergiler. } \\
\text { K9. Sporlara hazırlayııı oyun ve etkinliklerde bireysel gelişimi için } \\
\text { sorumluluk alır. } \\
\text { K11. Sporlara hazırlayıcı oyun ve etkinliklerde zamanı etkili kullanır. } \\
\text { K17. Sporlara hazırlayıcı oyun ve etkinliklerde karşılaştığı problemlere } \\
\text { bireysel çözümler üretir. } \\
\text { K18. Sporlara hazırlayıcı oyun ve etkinliklerde geliştirdiği } \\
\text { stratejileri/taktikleri uygular. } \\
\text { K19. Planladığı fiziksel etkinliklere düzenli olarak katılır. } \\
\text { K26. Millî bayramlar/belirli gün ve haftalar için hazırlanan etkinliklere } \\
\text { istekle katılır. } \\
\text { K27. Atatürk’ün spora ve sporculara neden önem verdiğini bilir. }\end{array}$ \\
\hline Orta Düzey Yeterlik & $\begin{array}{l}\text { K8. Sporlara hazırlayıcı oyun ve etkinliklerde kullandığı hareket } \\
\text { kavramlarını açıklar. } \\
\text { K10. Sporlara hazırlayıcı oyun ve etkinlikler için kural ve yönergeler } \\
\text { olușturulmasına katkı sağlar. } \\
\text { K16. Sporlara hazırlayıcı oyun ve etkinliklerde kendisinin ve } \\
\text { arkadaşlarının performanslarını değerlendirir. } \\
\text { K20. Fiziksel uygunluğunu geliştirecek hedefler belirleyerek, fiziksel } \\
\text { etkinlik programı hazırlar. } \\
\text { K21. Fiziksel etkinlik düzeyini etkileyen, kendisi ve yakın çevresi ile } \\
\text { ilgili nedenleri açıklar. } \\
\text { K22. Fiziksel uygunluk seviyesini takip ederek, zamanla oluşan } \\
\text { değişiklikleri açıklar. } \\
\text { K23. Fiziksel etkinlikler sırasında enerji veren ve sağlı̆ı̆ını koruyan } \\
\text { temel besin öğelerini açıklar. } \\
\text { K24. Fiziksel etkinliklerde kendisinin ve başkalarının sağlık ve } \\
\text { güvenlik risklerini azaltacak düzenlemeler yapar. } \\
\text { K25. Fiziksel etkinlikler sırasında karşılaştığı sağlık sorunlarını ve bu } \\
\text { sorunlardan korunma yöntemlerini bilir. }\end{array}$ \\
\hline Alt Düzey Yeterlik & $\begin{array}{l}\text { K5. Seçtiği cimnastik serisini uygular. } \\
\text { K6. Seçtiği müziğe uyumlu farklı dans becerileri sergiler. } \\
\text { K7. Halk danslarına özgü hareket becerileri sergiler. } \\
\text { K15. Sporlara hazırlayıcı oyun ve etkinliklerde kullanabileceği } \\
\text { materyaller tasarlar. } \\
\text { K28. Yakın çevresine ait halk danslarını araştırır. } \\
\text { K30. Olimpiyat oyunlarının önemini açıklar. } \\
\end{array}$ \\
\hline Yetersiz & $\begin{array}{l}\text { K2. Raket ve uzun saplı araçlarla yapılan sporlara hazırlayıcı } \\
\text { oyunlardaki ve etkinliklerdeki hareket becerilerini sergiler. } \\
\text { K4. Su sporları/etkinlikleri ile ilgili hareket becerileri sergiler. } \\
\text { K29. Farklı kültürlere ait çocuk oyunlarını araştırır. }\end{array}$ \\
\hline
\end{tabular}

www.turkishstudies.net/social 


\section{Ek 3.}

7. Sınıf Kazanımlarının Gerçekleşebilme Düzeylerine Göre Sınıflandırılması

\begin{tabular}{|c|c|}
\hline En Üst Düzey Yeterlik & $\begin{array}{l}\text { K13. Sporlara hazırlayıcı oyun ve etkinliklerde işbirliğine dayalı } \\
\text { davranışlar gösterir. } \\
\text { K14. Sporlara hazırlayıcı oyun ve etkinliklerde adil oyun anlayışına } \\
\text { uygun davranır. } \\
\text { K16. Sporlara hazırlayıcı oyun ve etkinliklerde bireysel farklılığı } \\
\text { olanlarla çalışmaya istekli olur. }\end{array}$ \\
\hline Üst Düzey Yeterlik & $\begin{array}{l}\text { K1. Bireysel ve takım sporlarına hazırlayıcı oyun ve etkinliklerdeki } \\
\text { hareket becerilerini artan bir doğrulukta sergiler. } \\
\text { K3. Doğada yapılan etkinliklerle ilgili becerileri geliştirir. } \\
\text { K8. Spor ve etkinliklere hazırlayıcı oyunlara katılırken ilgili hareket } \\
\text { kavramlarını yerinde kullanır. } \\
\text { K9. Sporlara hazırlayıcı oyun ve etkinliklerde kendi performansını analiz } \\
\text { eder. } \\
\text { K10. Sporlara hazırlayıcı oyun ve etkinliklerde karşılaştığı problemlere } \\
\text { eşle ve grupla çözümler üretir. } \\
\text { K11. Sporlara hazırlayıcı oyun ve etkinliklerde sorumluluk alır. } \\
\text { K12. Sporlara hazırlayıcı oyun ve etkinliklerde meydana gelen } \\
\text { anlaşmazlıklar için etkili iletişim yolları kullanır. } \\
\text { K15. Sporlara hazırlayıcı oyun ve etkinliklerde liderlik becerileri } \\
\text { gösterir. } \\
\text { K18. Akranının performansını değerlendirir. } \\
\text { K19. Sporlara hazırlayıcı oyunlar için strateji/taktik çözümler geliştirir. } \\
\text { K21. Yakın çevresindeki fiziksel etkinlik ve spor imkânlarını etkili } \\
\text { kullanır. } \\
\text { K20. Uyguladığı planın etkilerini gözleyerek fiziksel etkinliklere katıllır. } \\
\text { K22. Fiziksel etkinlik düzeyini korumak için kendini motive edecek } \\
\text { etkili yöntemleri tanır. } \\
\text { K23. Takip ettiği fiziksel etkinlik programının, fiziksel uygunluğuna } \\
\text { etkilerini açıklar. } \\
\text { K25. Fiziksel etkinlikler sırasında, kendisinin ve başkalarının sağlı̆ğını } \\
\text { destekleyecek ve güvenliğini sağlayacak davranışlar sergiler. } \\
\text { K28. Millî bayramlar/belirli gün ve haftalara çeşitli etkinlikler } \\
\text { hazırlayarak katılır. }\end{array}$ \\
\hline Orta Düzey Yeterlik & $\begin{array}{l}\text { K27. Fiziksel etkinlikler ve sporla ilgili güvenilir bilgi kaynaklarını } \\
\text { kullanır. } \\
\text { K29. Atatürk'ün spora ve sporcuya verdiği önemin ülkemize olan } \\
\text { katkılarını inceler. }\end{array}$ \\
\hline Alt Düzey Yeterlik & $\begin{array}{l}\text { K6. Seçtiği müziğe uyumlu yaratıcı dans koreografileri sergiler. } \\
\text { K5. Cimnastik serileri hazırlayarak uygular. } \\
\text { K7. Halk danslarına özgü hareket becerilerini artan bir doğrulukta } \\
\text { sergiler. } \\
\text { K17. Geliştirdiği materyali çeşitli spor ve etkinliklerde kullanır. } \\
\text { K24. Fiziksel etkinliklerde uygulayabileceği kişisel beslenme programını } \\
\text { hazırlar. } \\
\text { K26. Fiziksel etkinlikler sırasında karşılaştığı sağlık sorunlarında temel } \\
\text { ilk yardım uygulamalarını gösterir. } \\
\text { K30. Farklı yörelere ait halk danslarını araştırır. }\end{array}$ \\
\hline Yetersiz & $\begin{array}{l}\text { K2. Raket ve uzun saplı araçlarla yapılan sporlara hazırlayıcı oyun ve } \\
\text { etkinliklerde hareket becerilerini artan bir doğrulukta sergiler. } \\
\text { K4. Su sporları/etkinlikleri ile ilgili hareket becerilerini geliştirir. } \\
\text { K31. Ülkemizin olimpiyat tarihini araştırır. }\end{array}$ \\
\hline
\end{tabular}




\section{Ek 4.}

8. Sınıf Kazanımların Gerçekleşebilme Düzeylerine Göre Sınıflandırılması

\begin{tabular}{|c|c|}
\hline En Üst Düzey Yeterlik & $\begin{array}{l}\text { K2. Seçili spor dallarını yaparken spor dalına özgü ilke ve kuralları } \\
\text { uygular. } \\
\text { K4. Sportif etkinlikleri yaparken çevreye karşı duyarlı olur. } \\
\text { K12. Zihinsel ve bedensel engelin spor yapmaya engel olmadı̆ı̆ını bilir. } \\
\text { K16. Sportif etkinliklerde başkalarının haklarına saygı gösterir. } \\
\text { K22. Bireysel farklılıkları olanlarla sportif etkinlik yapmaya değer verir. } \\
\text { K24. Kendisinin ve grubunun hedeflerine ulaşmak için işbirliği içinde } \\
\text { olur. } \\
\text { K6. Seçili sportif etkinliklerle ilgili kavramları bilir. } \\
\text { K14. Araç-gereçleri ve alanlarını paylaşmaya değer verir. } \\
\text { K15. Sportif etkinliklere ilişkin düşüncelerini ifade eder. } \\
\text { K21. Sportif etkinliklere katılmaya, değer verir. }\end{array}$ \\
\hline Üst Düzey Yeterlik & $\begin{array}{l}\text { K1. Seçili spor dalına özgü hareketleri geliştirir. } \\
\text { K3. Sportif etkinliklerde kendisinin ve çevresindekilerin güvenliği için } \\
\text { önlemler alır. } \\
\text { K5. Farklı durumlara uygun hücum ve savunma stratejileri geliştirir. } \\
\text { K7. Sportif etkinliklerde karşılaştığı problemlere çözüm/çözümler üretir. } \\
\text { K8. Performansını geliştirmenin yollarını arar. } \\
\text { K10. Seçili spora özgü fiziksel etkinliklerde ısınma ve soğuma } \\
\text { hareketleri yapar. } \\
\text { K11. Çevresindeki spor malzemelerini, spor alanlarını tanıyarak } \\
\text { düzenlenen spor etkinliklerine katılır. } \\
\text { K13. Sportif etkinliklerde zamanı etkili kullanır. } \\
\text { K17. Sportif etkinlikler içerisindeki farklı rolleri seçerek, } \\
\text { sorumluluklarını yerine getirir. } \\
\text { K18. Sportif etkinliklerde kazanma ve kaybetme durumlarını duygularını } \\
\text { kontrollü davranışlarla gösterir. } \\
\text { K19. Sportif etkinliklerde başarıyı takdir eder. } \\
\text { K20. Farklı sportif etkinlikleri yaparken kendine güven duyar. } \\
\text { K23. Sportif etkinliklerde meydana gelebilecek anlaşmazlıkların çözümü } \\
\text { için çaba gösterir. } \\
\text { K25. Fiziksel uygunluğunu geliştirmek için düzenli olarak fiziksel } \\
\text { etkinlikler yapar. } \\
\text { K26. Sağlıklı yaşam için düzenli fiziksel etkinlik yapma alışkanlığı } \\
\text { kazanır. } \\
\text { K28. Sportif etkinlikler sonrasında kişisel bakımını ve temizliğini } \\
\text { yapmayı alışkanlık hâline getirir. } \\
\text { K29. Dengeli ve düzenli beslenmeyle fiziksel etkinlik arasındaki ilişkiyi } \\
\text { kurar. } \\
\text { K31. Temel ilk yardım ilkelerinin önemini bilir. } \\
\text { K32. Ulusal bayramları coşkuyla kutlamak için düzenlenen spor } \\
\text { etkinliklerine, halk oyunlarına ve dans gösterilerine değer vererek katılır. } \\
\text { K33. Çevresindekileri, düzenlenen ulusal bayramlar etkinliklerine } \\
\text { katıllmaya teşvik eder. } \\
\text { K36. Okul ççinde sınılar arası spor organizasyonları düzenlenmesinde } \\
\text { görev alır. } \\
\text { K37. Çeşitli spor olaylarını kitle iletişim araçlarından takip ederek } \\
\text { yorumlar. }\end{array}$ \\
\hline Orta Düzey Yeterlik & $\begin{array}{l}\text { K27. Fiziksel uygunluğunu geliştirmek için dengeli ve düzenli beslenme } \\
\text { alışkanlığı kazanır. } \\
\text { K30. Sağlıklı bir vücut ve fiziksel gelişim için dengeli ve düzenli } \\
\text { beslenme alışkanlığı kazanır. }\end{array}$ \\
\hline
\end{tabular}




\begin{tabular}{cl}
\hline \hline AIt Düzey Yeterlik & $\begin{array}{l}\text { K9. Performansını analiz etmek için mekaniğin ilkelerini kullanır. } \\
\text { K34. Atatürk'ün, spora ve sporculara verdiği önemi araştırarak } \\
\end{array}$ \\
& $\begin{array}{c}\text { çıarımlarda bulunur. } \\
\text { K35. Olimpiyat oyunlarının sosyal, kültürel ve ekonomik açıdan ülkelere } \\
\text { sağladığı katkıları araştırarak yorumlar. }\end{array}$ \\
\hline Yetersiz & \\
\hline \hline
\end{tabular}

